\title{
Methods of Analysis-Determination of Pesticides in Sediment Using Gas Chromatography/Mass Spectrometry
}

Techniques and Methods 5-C3 



\section{Methods of Analysis-Determination of Pesticides in Sediment Using Gas Chromatography/Mass Spectrometry}

By Michelle L. Hladik and Megan M. McWayne

Techniques and Methods 5-C3 


\title{
U.S. Department of the Interior \\ KEN SALAZAR, Secretary \\ U.S. Geological Survey \\ Marcia K. McNutt, Director
}

\author{
U.S. Geological Survey, Reston, Virginia: 2012
}

For more information on the USGS - the Federal source for science about the Earth, its natural and living resources, natural hazards, and the environment, visit http://www.usgs.gov or call 1-888-ASK-USGS.

For an overview of USGS information products, including maps, imagery, and publications, visit http://www.usgs.gov/pubprod

To order this and other USGS information products, visit http://store.usgs.gov

Any use of trade, product, or firm names is for descriptive purposes only and does not imply endorsement by the U.S. Government.

Although this report is in the public domain, permission must be secured from the individual copyright owners to reproduce any copyrighted materials contained within this report.

Suggested citation:

Hladik, M.L., and McWayne, M.M., 2012, Methods of analysis-Determination of pesticides in sediment using gas chromatography/mass spectrometry: U.S. Geological Survey Techniques and Methods 5-C3, 18 p. Available at http://pubs.usgs.gov/tm/tm5c3. 


\section{Contents}

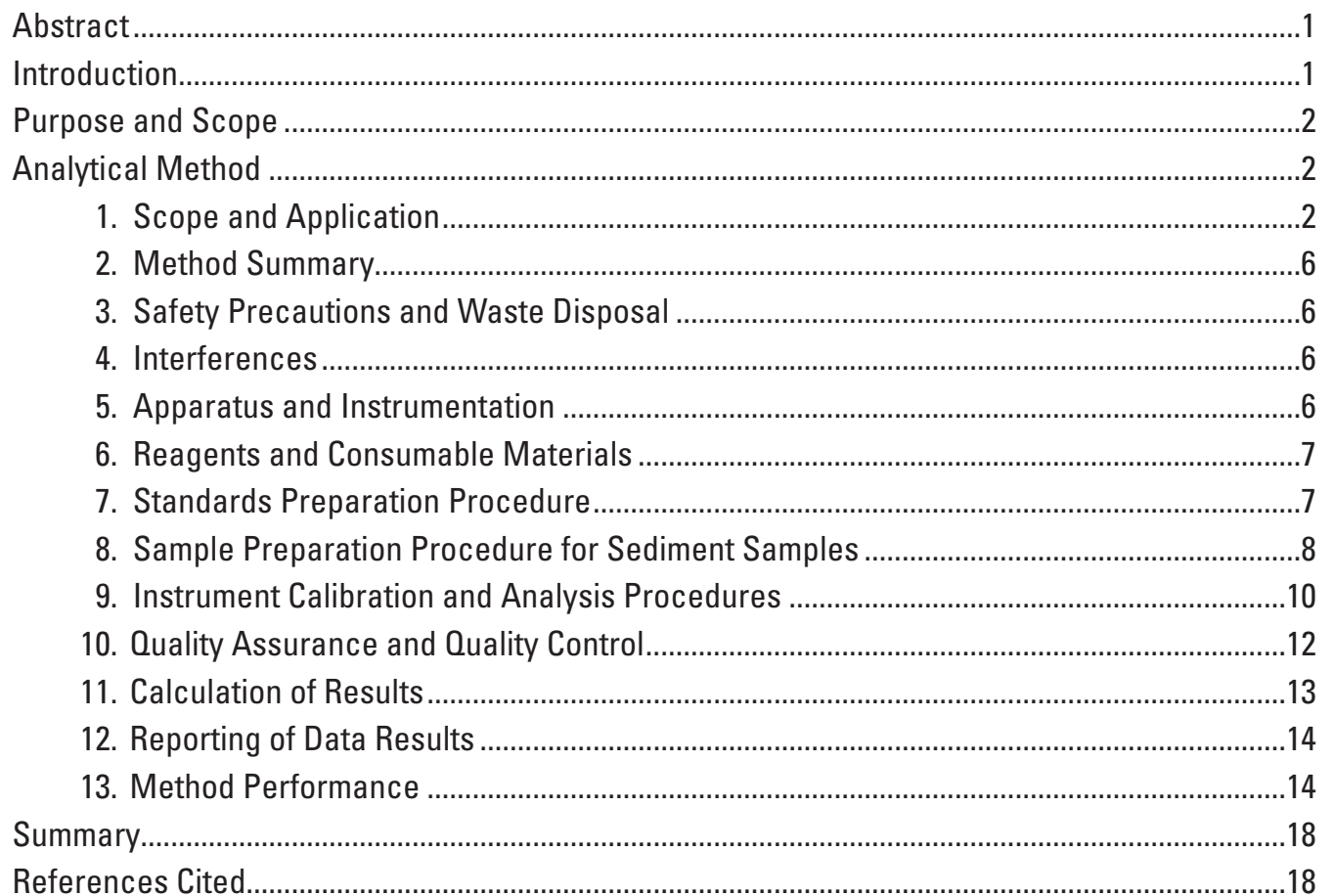

\section{Tables}

1. CAS Registry number, chemical class, type of pesticide, molecular weight and

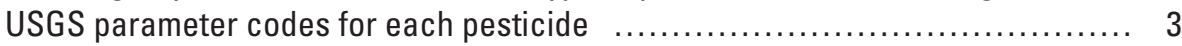

2. Retention times, quantitation ions and confirmation ions for pesticides analyzed

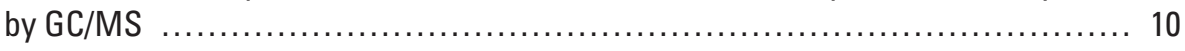

3. Example analytical sequence for use in determining pesticides in sediments ..... 13

4. Summary of method recovery and variability (expressed as mean percent recovery and relative standard deviation) and method detection limits determined from sets of 7 spiked samples of two different sediment matrixes $\quad \ldots 15$ 


\section{Conversion Factors}

SI to Inch/Pound

\begin{tabular}{lll}
\hline \multicolumn{1}{c}{ Multiply } & By & To obtain \\
\hline & Length & \\
\hline centimeter $(\mathrm{cm})$ & 0.3937 & inch (in.) \\
micrometer $(\mu \mathrm{m})$ & $3.937 \times 10^{-5}$ & inch (in) \\
millimeter $(\mathrm{mm})$ & 0.03937 & inch (in.) \\
meter $(\mathrm{m})$ & 3.281 & foot (ft) \\
\hline & Volume & gallon (gal) \\
\hline liter $(\mathrm{L})$ & 0.2642 & gallon (gal) \\
microliter $(\mu \mathrm{L})$ & $2.642 \times 10^{-7}$ & gallon (gal) \\
milliliter $(\mathrm{mL})$ & 0.000264 & ounce per minute \\
mL/min & 0.0338 & \\
\hline & \multicolumn{1}{c}{ Mass } & ounce, avoirdupois $(\mathrm{oz})$ \\
\hline gram $(\mathrm{g})$ & 0.03527 & pound, avoirdupois $(\mathrm{lb})$ \\
kilogram $(\mathrm{kg})$ & 2.205 & ounce, avoirdupois $(\mathrm{oz})$ \\
microgram $(\mu \mathrm{gg})$ & $3.527 \times 10^{-8}$ & ounce, avoirdupois $(\mathrm{oz})$ \\
milligram $(\mathrm{mg})$ & $3.527 \times 10^{-5}$ & ounce, avoirdupois $(\mathrm{oz})$ \\
nanogram $(\mathrm{ng})$ & $3.527 \times 10^{-11}$ & \\
\hline
\end{tabular}

Temperature in degrees Celsius $\left({ }^{\circ} \mathrm{C}\right)$ may be converted to degrees Fahrenheit $\left({ }^{\circ} \mathrm{F}\right)$ as follows:

${ }^{\circ} \mathrm{F}=\left(1.8 \mathrm{x}^{\circ} \mathrm{C}\right)+32$ 


\section{Conversion Factors-Continued}

Abbreviated units of measurement used in this report:

$\begin{array}{ll}\AA & \text { angstrom } \\ \mathrm{amu} & \text { atomic mass unit } \\ \mathrm{cm} & \text { centimeter } \\ \mathrm{g} & \text { gram } \\ \mathrm{i} . \mathrm{d} . & \text { inner diameter } \\ \mathrm{L} & \text { liter } \\ \mathrm{m} & \text { meter } \\ \mathrm{mg} & \text { milligram } \\ \mathrm{min} & \text { minute } \\ \mathrm{mL} & \text { milliliter } \\ \mathrm{mL} / \mathrm{min} & \text { milliliter per minute } \\ \mathrm{mm} & \text { millimeter } \\ \mathrm{m} / \mathrm{z} & \text { mass-to-charge ratio } \\ \mathrm{ng} & \text { nanogram } \\ \mathrm{ng} / \mu \mathrm{L} & \text { nanogram per microliter } \\ \mathrm{nm} & \text { nanometer } \\ \mathrm{psi} & \text { pound per square inch } \\ \mu \mathrm{g} / \mathrm{kg} & \text { microgram per gram } \\ \mu \mathrm{g} / \mathrm{mL} & \text { microgram per milliliter } \\ \mu \mathrm{L} & \text { microliter } \\ \mu \mathrm{m} & \text { micrometer (micron) }\end{array}$




\section{Conversion Factors-Continued}

Other abbreviations used in this report

(additional information or clarification given in parentheses)

\begin{tabular}{|c|c|}
\hline ACS & American Chemical Society \\
\hline $\operatorname{ASE}^{\circledR}$ & accelerated solvent extraction \\
\hline ASTM & American Society for Testing and Materials \\
\hline C & sample concentration (equations 1, 2, 4 and 5) \\
\hline CAS & Chemical Abstracts Service (American Chemical Society) \\
\hline CCV & continuing calibration verification \\
\hline DCM & dichloromethane \\
\hline E & extract concentration (equation 3 ) \\
\hline El & electron ionization \\
\hline EtOAc & ethyl acetate \\
\hline GC & gas chromatograph \\
\hline GC/MS & gas chromatography with mass spectrometry \\
\hline GF/F & glass-fiber filter (grade GF/F) \\
\hline GPC & gel-permeation chromatography \\
\hline HPLC & high-performance liquid chromatograph \\
\hline ISTD & internal standard \\
\hline MDL & method detection limit (text and equation 6) \\
\hline MS & mass spectrometer \\
\hline NAWQA & National Water Quality Assessment (USGS) \\
\hline PAH & polycyclic aromatic hydrocarbon \\
\hline PFTBA & perfluorotributylamine \\
\hline PPE & personal protective equipment \\
\hline $\mathrm{QA}$ & quality assurance \\
\hline $\mathrm{QA} / \mathrm{QC}$ & quality assurance and quality control \\
\hline $\mathrm{QC}$ & quality control \\
\hline RF & response factor (equation 2) \\
\hline RPD & relative percent difference \\
\hline RSD & relative standard deviation \\
\hline SIM & selected ion monitoring \\
\hline SPE & solid-phase extraction \\
\hline USEPA & U.S. Environmental Protection Agency \\
\hline USGS & U.S. Geological Survey \\
\hline UV-Vis & ultraviolet and visible light \\
\hline $\mathrm{v} / \mathrm{v}$ & volume-to-volume \\
\hline Wd & dry weight of sediment extracted (equation 3) \\
\hline Ww & wet weight of sediment extracted (equation 34) \\
\hline
\end{tabular}




\title{
Methods of Analysis-Determination of Pesticides in Sediment By Using Gas Chromatography/ Mass Spectrometry
}

\author{
By Michelle L. Hladik and Megan M. McWayne
}

\section{Abstract}

A method for the determination of 119 pesticides in environmental sediment samples is described. The method was developed by the U.S. Geological Survey (USGS) in support of the National Water Quality Assessment (NAWQA) Program. The pesticides included in this method were chosen through prior prioritization. Herbicides, insecticides, and fungicides along with degradates are included in this method and span a variety of chemical classes including, but not limited to, chloroacetanilides, organochlorines, organophosphates, pyrethroids, triazines, and triazoles.

Sediment samples are extracted by using an accelerated solvent extraction system $\left(\mathrm{ASE}^{\circledR}\right)$, and the compounds of interest are separated from co-extracted matrix interferences (including sulfur) by passing the extracts through high performance liquid chromatography (HPLC) with gel-permeation chromatography (GPC) along with the use of either stacked graphitized carbon and alumina solid-phase extraction (SPE) cartridges or packed Florisil ${ }^{\circledR}$. Chromatographic separation, detection, and quantification of the pesticides from the sediment-sample extracts are done by using gas chromatography with mass spectrometry (GC/MS).

Recoveries in test sediment samples fortified at 10 micrograms per kilogram $(\mu \mathrm{g} / \mathrm{kg})$ dry weight ranged from 75 to 102 percent; relative standard deviations ranged from 3 to 13 percent. Method detection limits (MDLs), calculated by using U.S. Environmental Protection Agency procedures (40 CFR 136, Appendix B), ranged from 0.6 to $3.4 \mu \mathrm{g} / \mathrm{kg}$ dry weight.

\section{Introduction}

Pesticides are of environmental concern in streams in both the water column and sediment. Those pesticides that are more hydrophobic tend to be detected more frequently in sediment; thus, measuring pesticides in sediment is important for tracking their fate in the environment and evaluating for potential toxicity. Determining priority pesticides for analysis in water and sediment has been undertaken by the U.S. Geological Survey (USGS) by using a broad approach to address multiple USGS program goals, including the upcoming third decade (Cycle 3) of sampling for the National Water Quality Assessment (NAWQA) Program (Norman and others, 2012).

Multiple methods exist to measure pesticides at environmentally relevant concentrations, including one method already developed by the USGS Organic Chemistry Laboratory in Sacramento, Calif. (Sacramento Laboratory) for sediment (Smalling and Kuivila, 2008; Hladik and others, 2009c). The previously developed Sacramento Laboratory sediment method (with slight modifications made over the years) has been robust across many types of sediments (bed and suspended sediment; varying percent organic carbon), with matrix-spike recoveries greater than 70 percent and with values of relative percent difference (RPD) between replicate samples of less than 25 percent (Orlando and others, 2008; Smalling and Kuivila, 2008; Hladik and others, 2009a; Smalling and Orlando, 2011; Orlando and others, U.S. Geological Survey, written commun., 2012; Smalling and others, 2012). The most recent version of the Sacramento Laboratory sediment method (Orlando and others, U.S. Geological Survey, written commun., 2012; Smalling and others, 2012) uses gas chromatography with mass spectrometry (GC/MS), and included 91 pesticides and pesticide degradates with method detections levels (MDLs) from 1 to $4 \mu \mathrm{g} / \mathrm{kg}$.

As the NAWQA Program prepares for Cycle 3, additional pesticides have been prioritized as those of interest for future studies (Norman and others, 2012). The Sacramento Laboratory is updating the current sediment method to include many of these prioritized pesticides. Because the current method has been shown to perform well across a wide range of percent sediment organic carbon concentrations (up to 36 percent), the method itself is not being modified; rather, additional compounds of interest to NAWQA Cycle 3 (that is, those classified as Tier 1 in the pesticide prioritization; Norman and others, 2012) and the Sacramento Laboratory are being added to the existing method. Additional compounds of interest were tested and dropped from the method if they were not amenable to analysis via $\mathrm{GC} / \mathrm{MS}$ or if initial recoveries were not greater than 70 percent. The updated method will evaluate sediment samples for 119 pesticides and pesticide degradates. 


\section{Purpose and Scope}

This report describes a method for the extraction and quantification of 119 pesticides from sediment samples by using GC/MS. The method described in this report was developed by the USGS Sacramento Laboratory to support the broad-spectrum analysis of pesticides in sediment by the NAWQA Program. This method expands the previously published method (original method: Smalling and Kuivila, 2008; most recent analyte list: Smalling and others, 2012) and increases the number of target analytes from 91 to 119 . The 28 new target analytes include high-priority pesticides from Norman and others (2012) that are amenable to analysis by GC/MS and met performance criteria. Sediment samples were extracted by using the accelerated solvent extraction system $\left(\mathrm{ASE}^{\circledR}\right)$, followed by high performance liquid chromatography (HPLC) with gel-permeation chromatography (GPC) for sulfur removal, with additional cleanup of the matrix interferences that occur in sediment extracts performed with the use of either carbon/alumina solid-phase extraction (SPE) or Florisil ${ }^{\circledR}$. Pesticides were quantified by GC/MS. This report also provides extraction recoveries along with the analytical precision (expressed as relative standard deviation(RSD)) and MDLs.

The method of analysis described in this report is assigned USGS method numbers O-6144-12 (bed sediment) and 0-7144-12 (suspended sediment), USGS method codes GM031 (suspended sediment) and GM032 (bed sediment), and Sacramento Laboratory code NAWQA3. These unique codes represent the type of analysis described in the report, which can be used to identify the method. This procedure provides an effective option to environmental scientists seeking pesticide analyses in sediment samples, with minimal contamination bias, relatively low MDLs, good recoveries, and excellent precision. The method will contribute to the improved understanding of the occurrence, fate, and transport of pesticides in the environment.

\section{Analytical Method}

Organic Compounds and Parameter Codes: Pesticides in bed sediment or suspended sediment using $\mathrm{ASE}^{\circledR}$, HPLC-GPC, SPE/Florisil ${ }^{\circledR}$, and GC/MS-USGS method numbers O-6144-12 (bed sediment) and O-7133-12 (suspended sediment), USGS method codes GM031 (suspended sediment) and GM032 (bed sediment), and Sacramento Laboratory code NAWQA3.

\section{Scope and Application}

This method is suitable for determining the pesticides listed in table 1, at microgram-per-kilogram concentrations in sediment samples. The compound names, Chemical Abstracts Service (CAS) numbers, chemical classes, pesticide types, molecular weights, and USGS parameter codes are listed in table 1. Compounds that are being added to the existing method in this update are identified with an asterisk next to the compound name. These are the compounds that met the recovery and detection-level criteria for inclusion. An additional 64 compounds were considered for the new method; 7 of the compounds (mostly degradates) did not have standards available, 44 compounds were not amenable to GC analysis, and 13 compounds were not able to be recovered at levels greater than 70 percent through the sediment extraction and cleanup. 
Table 1. CAS Registry number, chemical class, type of pesticide, molecular weight and USGS parameter codes for each pesticide.

[Compounds noted with an asterisk have not been reported in a previous method. This report contains Chemical Abstracts Service Registry Numbers (CASRN), which is a Registered Trademark of the American Chemical Society. Chemical Abstracts Service (CAS) recommends the verification of the CASRNs through CAS Client Services. The five-digit parameter codes are used by the U.S. Geological Survey to uniquely identify a specific constituent or property in the National Water Information System (NWIS) database. Abbreviations/Acronyms: amu, atomic mass unit; NA, not available]

\begin{tabular}{|c|c|c|c|c|c|c|}
\hline Compound & CASRN & Chemical class & $\begin{array}{l}\text { Pesticide } \\
\text { type }\end{array}$ & $\begin{array}{c}\text { Molecular } \\
\text { weight } \\
\text { (amu) }\end{array}$ & $\begin{array}{l}\text { Bed- } \\
\text { sedment } \\
\text { parameter } \\
\text { code }\end{array}$ & $\begin{array}{l}\text { Suspended- } \\
\text { sediment } \\
\text { parameter } \\
\text { code }\end{array}$ \\
\hline 2-Chloro-2,6-Diethylacetanilide* & $6967-29-9$ & Chloroacetanilide & Degradate & 225.7 & 68876 & 68875 \\
\hline 3,4-Dichloroaniline & $95-76-1$ & Aniline & Degradate & 162.0 & 66585 & 63400 \\
\hline 3,5-Dichloroaniline & $626-43-7$ & Aniline & Degradate & 162.0 & 67538 & 67537 \\
\hline Atrazine & $1912-24-9$ & Triazine & Herbicide & 215.7 & 39631 & 04017 \\
\hline Azinphos-methyl* & $86-50-0$ & Organophosphate & Insecticide & 317.3 & 64150 & 65115 \\
\hline Azoxystrobin & $131860-33-8$ & Strobilurin & Fungicide & 403.4 & 66591 & 66590 \\
\hline Benfluralin (Benefin)* & $1861-40-1$ & Dinitroaniline & Herbicide & 335.3 & 68878 & 68877 \\
\hline Bifenthrin & $82657-04-3$ & Pyrethroid & Insecticide & 422.9 & 64151 & 63415 \\
\hline Carbaryl & $63-25-2$ & Carbamate & Insecticide & 201.2 & 64153 & 65117 \\
\hline Carbofuran & $1563-66-2$ & Carbamate & Insecticide & 221.3 & 64154 & 65118 \\
\hline Chlorothalonil & $1897-45-6$ & Chloronitrile & Fungicide & 265.9 & 62904 & 65119 \\
\hline Chlorpyrifos & $2921-88-2$ & Organophosphate & Insecticide & 350.6 & 81404 & 65120 \\
\hline Clomazone & $81777-89-1$ & Isoxazlidinone & Herbicide & 239.7 & 67564 & 67563 \\
\hline Coumaphos* & $56-72-4$ & Organophosphate & Insecticide & 362.8 & 68882 & 68881 \\
\hline Cyhalofop-butyl* & $122008-85-9$ & Aryloxyphenoxypropionate & Herbicide & 357.4 & 68884 & 68883 \\
\hline Cycloate & $1134-23-2$ & Thiocarbamate & Herbicide & 215.4 & 64155 & 65121 \\
\hline Cyfluthrin & $68359-37-5$ & Pyrethroid & Insecticide & 434.3 & 65109 & 65122 \\
\hline Cyhalothrin & $68085-85-8$ & Pyrethroid & Insecticide & 449.9 & 68356 & 68355 \\
\hline Cypermethrin & $52315-07-8$ & Pyrethroid & Insecticide & 416.3 & 64156 & 65123 \\
\hline EPTC & $759-94-4$ & Thiocarbamate & Herbicide & 189.3 & 64158 & 65128 \\
\hline Esfenvalerate & $66230-04-4$ & Pyrethroid & Insecticide & 419.9 & 64159 & 65129 \\
\hline Ethalfluralin & $55283-68-6$ & Aniline & Herbicide & 333.3 & 64160 & 65130 \\
\hline Etofenprox & 80844-07-1 & Pyrethroid & Insecticide & 376.5 & 67606 & 67605 \\
\hline Famoxadone & $131807-57-3$ & Oxazole & Fungicide & 374.4 & 67611 & 67610 \\
\hline Fenarimol & $60168-88-9$ & Pyrimidine & Fungicide & 331.2 & 67615 & 67614 \\
\hline Fenbuconazole & $114369-43-6$ & Triazole & Fungicide & 336.8 & 67620 & 67619 \\
\hline Fenhexamide & $126833-17-8$ & Anilide & Fungicide & 302.2 & 67624 & 67622 \\
\hline Fenpropathrin & $39515-41-8$ & Pyrethroid & Insecticide & 349.4 & 65111 & 65131 \\
\hline Fenpyroximate* & $134098-61-6$ & Pyrazole & Insecticide & 421.5 & 68888 & 68887 \\
\hline Fenthion* & $55-38-9$ & Organophosphate & Insecticide & 278.3 & 62046 & 68889 \\
\hline Fipronil & $120068-37-3$ & Phenylpyrazole & Insecticide & 437.2 & 66606 & 66605 \\
\hline Fipronil desulfinyl & NA & Phenylpyrazole & Insecticide & 389.1 & 66609 & 66608 \\
\hline Fipronil desulfinyl amide & NA & Phenylpyrazole & Insecticide & 421.1 & 68891 & 68890 \\
\hline
\end{tabular}

(Desulfinylfipronil amide)* 
Table 1. CAS Registry number, chemical class, type of pesticide, molecular weight and USGS parameter codes for each pesticide. Compounds noted with an asterisk have not been reported in a previous method._-Continued

[Compounds noted with an asterisk have not been reported in a previous method. This report contains Chemical Abstracts Service Registry Numbers (CASRN), which is a Registered Trademark of the American Chemical Society. Chemical Abstracts Service (CAS) recommends the verification of the CASRNs through CAS Client Services. The five-digit parameter codes are used by the U.S. Geological Survey to uniquely identify a specific constituent or property in the National Water Information System (NWIS) database. Abbreviations/Acronyms: amu, atomic mass unit; NA, not available]

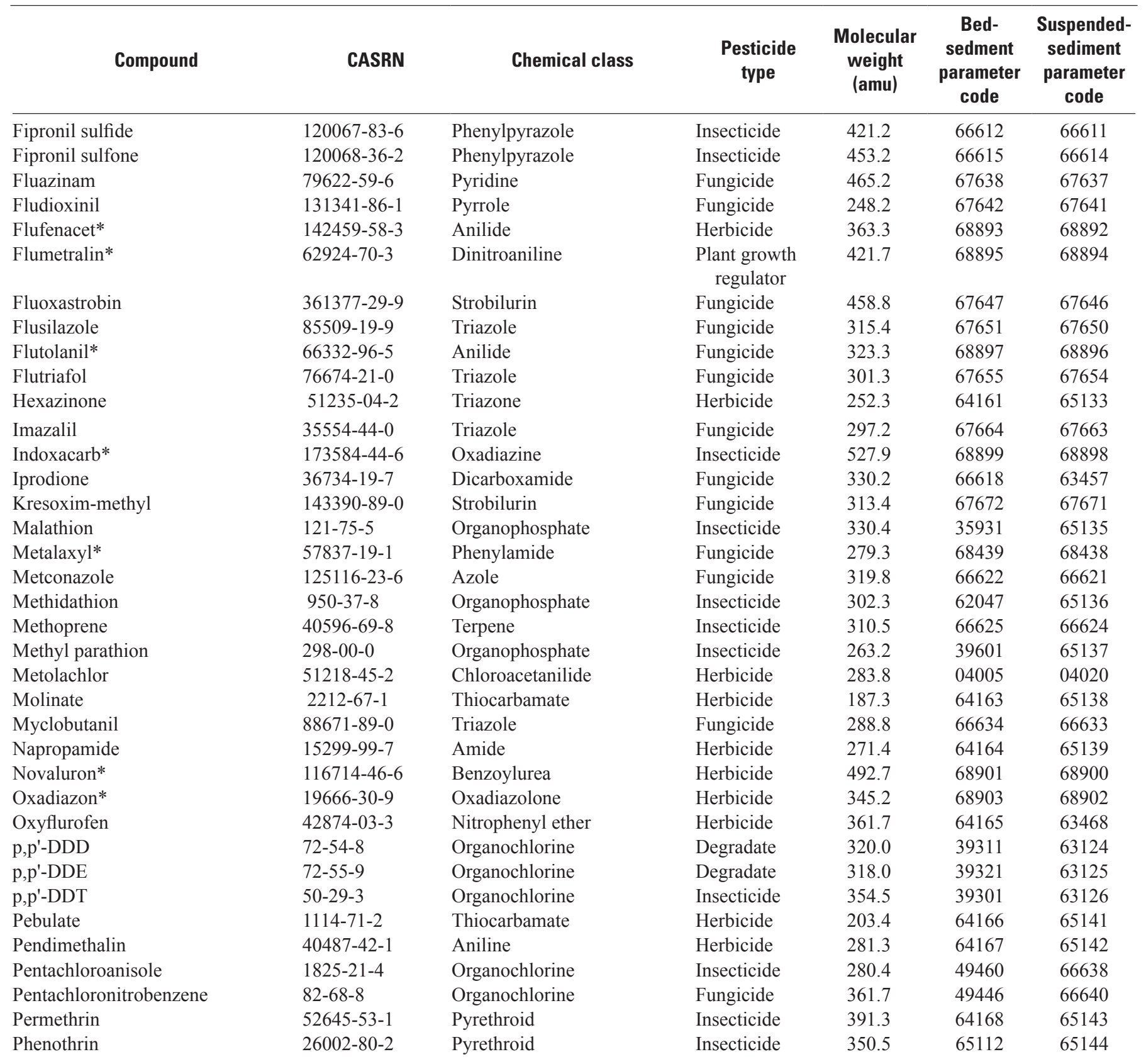


Table 1. CAS Registry number, chemical class, type of pesticide, molecular weight and USGS parameter codes for each pesticide. Compounds noted with an asterisk have not been reported in a previous method.-Continued

[Compounds noted with an asterisk have not been reported in a previous method. This report contains Chemical Abstracts Service Registry Numbers (CASRN), which is a Registered Trademark of the American Chemical Society. Chemical Abstracts Service (CAS) recommends the verification of the CASRNs through CAS Client Services. The five-digit parameter codes are used by the U.S. Geological Survey to uniquely identify a specific constituent or property in the National Water Information System (NWIS) database. Abbreviations/Acronyms: amu, atomic mass unit; NA, not available]

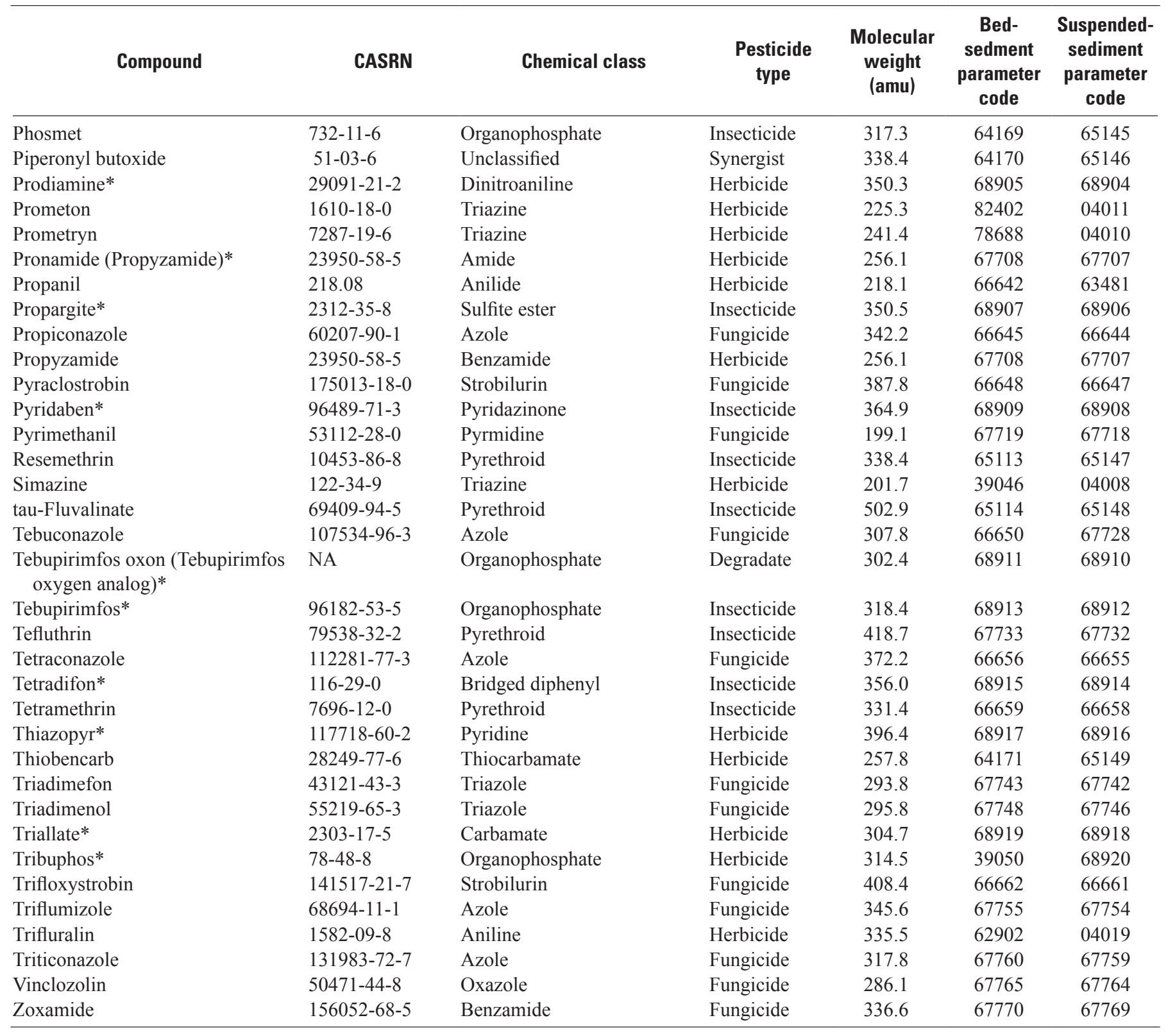




\section{Method Summary}

Sediment samples are collected in the field by using methods such as those outlined by Radtke (2005), and were typically collected in 500-mL amber glass jars. Samples are chilled immediately, shipped to the Sacramento Laboratory, and frozen at $-20^{\circ} \mathrm{C}$ until analysis (within 6 months). For extraction, the samples are thawed, and the percentage moisture is calculated. The samples ( $\sim 10 \mathrm{~g}$ dry weight) are extracted with an $\mathrm{ASE}^{\circledR}$ using dichloromethane (DCM). The extract is reduced under nitrogen to $0.5 \mathrm{~mL}$ using a TurboVap ${ }^{\circledR}$ system and exchanged into ethyl acetate (EtOAc). Removal of sulfur is achieved by HPLC-GPC of the extract. The GPC eluent is evaporated in a hood using a gentle stream of nitrogen to a volume of $2.0 \mathrm{~mL}$, and then split equally into two $1.0 \mathrm{~mL}$ aliquots for either herbicide/insecticide analysis via stacked carbon/alumina SPE or fungicide analysis (which also includes one each of an herbicide, insecticide, and degradate) via Florisil ${ }^{\circledR}$ clean-up.

The herbicide/insecticide fraction (78 target compounds) is exchanged into DCM to undergo additional cleanup on stacked graphitized carbon and alumina SPE cartridges. The compounds of interest are eluted from the SPE cartridge with DCM and then additionally from the alumina cartridge with 50:50 DCM:EtOAc v/v. The eluents are combined and exchanged into EtOAc. The fungicide fraction (41 target compounds) is exchanged into hexane and put through packed Florisi ${ }^{\mathbb{R}}$ (6 percent deactivated) as an additional cleanup step. Compounds are eluted from the Florisil ${ }^{\circledR}$ with 20 percent DCM in hexane followed by 50 percent EtOAc in hexane.

Following either the carbon/alumina or Florisi ${ }^{\circledR}$ procedures, eluents are separately reduced to $\sim 0.2 \mathrm{~mL}$ under a gentle steam of nitrogen and exchanged to EtOAc. Deuterated polycyclic aromatic hydrocarbon $(\mathrm{PAH})$ internal standards are added prior to analysis. The concentrations of the pesticides in the two extracts are determined by GC/MS.

\section{Safety Precautions and Waste Disposal}

The following safety precautions are followed:

3.1 All steps that use organic solvents are performed in a well-vented fume hood.

3.2 The $\mathrm{ASE}^{\circledR}$ exhaust and TurboVap ${ }^{\circledR}$ exhaust must be vented to a fume hood. The HPLC-GPC is contained in a fume hood.

\subsection{Appropriate personal protective equipment (PPE)}

(eyewear, gloves, etc.) is used during the handling of reagents and chemicals. Disposable nitrile gloves do not provide adequate protection from DCM. Polyvinyl acetate gloves will provide adequate protection. Alternatively, the analyst may wear double nitrile gloves, but if DCM comes in contact with the nitrile gloves, the gloves must be removed immediately.
3.4 Precautions are taken when handling the gas chromatograph (GC) injector or working with the mass spectrometer (MS), because temperatures in their heated zones can be near $300^{\circ} \mathrm{C}$. These areas must be allowed to cool before touching them. Laboratory staff will have received training in the Occupational Safety and Health Administration (OSHA) Hazard Communication standard and will be familiar with the properties of the reagents and target compounds prior to using this method.

3.5 All liquid waste produced during the extraction is considered "organic waste" and must be placed in thick-walled carboys and disposed of according to local regulations. The solid-waste stream produced during sample analysis comprises SPE cartridges, extracted sediment or soil, sodium sulfate, and assorted disposable glassware (such as glass pipettes and $\mathrm{GC}$ vials). Once the solid-waste items have been dried in a hood (that is, until no organic solvent remains), they can be disposed of according to local policy.

\section{Interferences}

Compounds that compete with or co-elute with the compounds of interest from the SPE cartridge materials or the Florisi $l^{\circledR}$ might cause interferences or low method recoveries. In addition, humic and fulvic acids might also cause interferences or reduce extraction efficiency, thus lowering pesticide recoveries. Possible interferences are addressed with matrix-spiked samples and surrogate compounds.

The purpose of representative sampling is to characterize the true concentration of pesticides in environmental samples. Field and laboratory personnel should be aware that many of the compounds included in this study are common ingredients in household pesticide products, and exposure to these products should be limited prior to sample collection or sample handling. The potential for contamination bias during sample collection or handling is monitored by the use of field blanks and laboratory blanks.

\section{Apparatus and Instrumentation}

The following apparatus and instrumentation are used:

5.1 Analytical Balances - Balances for sediment samples capable of accurately weighing $5.00 \mathrm{~g} \pm 0.01 \mathrm{~g}$. Balance for standard preparation accurately weighs $5.000 \mathrm{mg} \pm 0.001 \mathrm{mg}$.

5.2 Accelerated Solvent Extraction System-Thermo Fisher Scientific ${ }^{\circledR}$ Dionex (Sunnyvale, Calif.) ASE ${ }^{\circledR} 350$ including precleaned stainless-steel extraction vessels and glass collection vials.

5.3 TurboVap ${ }^{\circledR}$ —Zymark Corporation (Hopkinton, Mass.) TurboVap ${ }^{\circledR}$ II Concentration Evaporation Workstation, including precleaned glass tubes ( 0.2 to $1.0 \mathrm{~mL}$ graduated). 
5.4 N-evap - Organomation Associates, Inc. (Berlin, Mass.) N-EVAP Nitrogen Evaporator and 12-mL glass concentrator tubes.

5.5 SPE vacuum manifold - Includes vial rack to hold $15-\mathrm{mL}$ glass concentrator tubes.

5.6 SPE cartridges - CarboPrep ${ }^{\circledR} 90$ graphitized carbon cartridges (6 cc, $500 \mathrm{mg}$, Restek, Bellefonte, Pa.) stacked on top of Sep-Pak Alumina A cartridges (500 mg, Waters, Milford, Mass.).

5.7 Cleanup columns-Fisher Scientific (Fair Lawn, N.J.) 60-100 mesh Florisil ${ }^{\circledR}$ activated magnesium sulfate and precleaned $200 \mathrm{~mL}$ glass columns $400 \mathrm{~mm} \mathrm{~L} \times 10 \mathrm{~mm}$ i.d.

5.8 HPLC-GPC bench-top system-Scientific Systems Inc. (State College, Pa.) Series I isocratic HPLC pump and ultraviolet-visible (UV-Vis) detector (set to $254 \mathrm{~nm}$ ) with a PL-gel guard column $(10 \mu \mathrm{m}, 50 \times 7.5 \mathrm{~mm}$; Agilent Technologies, Santa Clara, Calif.) and PL-gel analytical column $(10 \mu \mathrm{m}, 50 \AA, 300 \times 7.5 \mathrm{~mm}$; Agilent Technologies, Santa Clara, Calif.).

5.9 GC/MS bench-top system-Agilent Technologies 7890A GS coupled to an Agilent 5975C Inert XL EI/CI MS with Chemstation software $v 2008$ and a Leap Technologies (Carrboro, N.C.) CTC Combi PAL autosampler.

5.10 GC/MS analytical column-DB-5ms (30 $\mathrm{m} \times 0.25 \mathrm{~mm} \times$ $0.25 \mu \mathrm{m}$; Agilent Technologies, Santa Clara, Calif.).

5.11 Precleaned glassware including pipettes, microsyringes, concentrator tubes, funnels, and graduated cylindersEverything but the microsyringes are baked at $450^{\circ} \mathrm{C}$ for a minimum of 4 hours.

\section{Reagents and Consumable Materials}

6.1 Analytical standards - Neat solutions of pesticides obtained from the U.S. Environmental Protection Agency (USEPA) National Pesticide Standard Repository (Fort Meade, Md.).

6.2 Internal standards (ISTD) - Neat solutions of the ISTDs, $d_{10}$-acenaphthene and $d_{10}$-pyrene (Cambridge Isotope Laboratories, Andover, Mass.).

6.3 Surrogate standards - The surrogates: ring- ${ }^{13} \mathrm{C}_{12}-p, p$ 'DDE and di- $N$-propyl- $d_{14}$-trifluralin at $100 \mu \mathrm{g} / \mathrm{mL}$; phenoxy- ${ }^{13} \mathrm{C}_{6}$-cis-permethrin at $50 \mu \mathrm{g} / \mathrm{mL}$ (Cambridge Isotope Laboratories, Andover, Mass.).

6.4 Deionized water - Generated by purification of tap water to American Society of Testing and Materials (ASTM) Type II water or better (Picosystem ${ }^{\circledR}$ Plus, Hydro Service and Supplies, Inc., Durham, N.C.).
6.5 Solvents-Acetone, DCM, hexane, EtOAc; all Fisher Scientific (Fair Lawn, N.J.) Optima grade or better.

6.6 Sodium sulfate, anhydrous - Granular, 10-60 mesh, American Chemical Society (ACS)-certified (Thermo Fisher Scientific, Pittsburgh, Pa.), baked at $450^{\circ} \mathrm{C}$ for a minimum of 4 hours.

6.7 Glass-fiber syringe filters-25-mm diameter, $0.7-\mu \mathrm{m}$ nominal pore size, GF/F-grade glass-fiber filters with GD/X disposable polypropylene housing (Whatman, Piscataway, N.J.).

6.8 SPE cartridges - Carboprep 90 graphitized carbon cartridges (6 cc, $500 \mathrm{mg}$, Restek, Bellefonte, Pa.) stacked on top of Sep-Pak Alumina A cartridges (500 mg, Waters, Milford, Mass.) .

6.9 Florisil—Fisher Scientific (Fair Lawn, N.J.) 60-100 Mesh Florisil and precleaned $200 \mathrm{~mL}$ glass columns $400 \mathrm{~mm} \mathrm{~L} \times 10 \mathrm{~mm}$ i.d. The Florisil ${ }^{\circledR}$ is previously activated at $550^{\circ} \mathrm{C}$ in a muffle furnace for 16 hours and removed at $100^{\circ} \mathrm{C}$. The activated Florisil ${ }^{\circledR}$ is deactivated by adding hexane-washed deionized water, 6 percent by weight; to do this, multiply the mass of activated Florisil ${ }^{\circledR}$ by 0.06 to determine the appropriate amount of water to add. The water is added in 4-5 mL aliquots with 5 minute intervals of shaking between each addition until the calculated amount of water is added. Allow the Florisil ${ }^{\circledR}$ to equilibrate in a tightly closed container overnight in a dessicator.

6.10 Helium carrier gas (99.999 percent pure) — GC carrier gas, local supplier.

6.11 Nitrogen gas (99.999 percent pure) - For evaporation of organic solvent and extraction gas for $\mathrm{ASE}^{\circledR}$, local supplier.

\section{Standards Preparation Procedure}

7.1 Primary standard solutions - Individual stock solutions of $1,000 \mathrm{ng} / \mu \mathrm{L}$ for each pesticide and ISTD are prepared by accurately weighing, to the nearest $0.01 \mathrm{mg}, 4-5 \mathrm{mg}$ of the pure material into a $7-\mathrm{mL}$ amber glass vial. Add $1 \mathrm{~mL}$ of acetone (using a microsyringe) per milligram of the weighed compound.

7.2 Herbicide/insecticide concentrated stock solutionsTwo stock solutions containing $20 \mathrm{ng} / \mu \mathrm{L}$ of each herbicide insecticide are prepared by diluting individual $1,000 \mathrm{ng} / \mu \mathrm{L}$ primary standard solutions $(0.5 \mathrm{~mL}$ each $)$ into EtOAc in a $25-\mathrm{mL}$ volumetric flask. Half of the herbicide/ insecticide compounds go into one stock solution and the other half go into the second stock solution because there are 78 target compounds and they cannot all be added to a single 25 -mL volumetric flask. 
7.3 Fungicide concentrated stock solution - Stock solution containing $20 \mathrm{ng} / \mu \mathrm{L}$ of each fungicide is prepared by diluting individual $1,000-\mathrm{ng} / \mu \mathrm{L}$ primary standard solutions $(0.5 \mathrm{~mL}$ each) into EtOAc in a $25-\mathrm{mL}$ volumetric flask.

7.4 ISTD stock solution-Stock solution containing $10 \mathrm{ng} / \mu \mathrm{L}$ of ISTD is prepared by diluting $1.0 \mathrm{~mL}$ of each $1,000-\mathrm{ng} / \mu \mathrm{L}$ ISTD primary standard solution into EtOAc in a $100-\mathrm{mL}$ volumetric flask.

7.5 Herbicide/insecticide standard solutions - Two solutions containing $10 \mathrm{ng} / \mu \mathrm{L}$ of pesticides and surrogate are prepared by diluting $5.0 \mathrm{~mL}$ of the herbicide/insecticide stock solutions (the two $20 \mathrm{ng} / \mu \mathrm{L}$ solutions from 7.2) plus $1.0 \mathrm{~mL}$ of ITSD stock solution (10 ng/ $\mu \mathrm{L}$ from 7.4) into EtOAc in two separate 10 -mL volumetric flasks.

7.6 Fungicide standard solution - Solution containing $10 \mathrm{ng} / \mu \mathrm{L}$ of fungicides is prepared by diluting $5 \mathrm{~mL}$ of the fungicide stock solution (the $20 \mathrm{ng} / \mu \mathrm{L}$ solution from 7.3) and $1.0 \mathrm{~mL}$ of ITSD stock solution $(10 \mathrm{ng} / \mu \mathrm{L}$ from 7.4) into EtOAc in a $10-\mathrm{mL}$ volumetric flask.

7.7 Surrogate standard solution - Solution containing $10 \mathrm{ng} / \mu \mathrm{L}$ of surrogate material is prepared by adding 0.5 or $1.0 \mathrm{~mL}$ of the concentrated surrogates (depending on if their initial concentration was 100 or $50 \mathrm{ng} / \mu \mathrm{L}$, respectively) plus $1 \mathrm{~mL}$ of the internal standard stock $(10 \mathrm{ng} / \mu \mathrm{L})$ into EtOAc in a $5-\mathrm{mL}$ volumetric flask.

7.8 Dilute ISTD solution-Solution containing $1 \mathrm{ng} / \mu \mathrm{L}$ of ISTD is prepared by diluting $5 \mathrm{~mL}$ of $10 \mathrm{ng} / \mu \mathrm{L}$ ISTD stock solution into EtOAc in a $50-\mathrm{mL}$ volumetric flask.

7.9 Calibration solutions - In EtOAc, prepare two series, herbicides/insecticides and fungicides, of calibration solutions (no fewer than five concentrations) that contain all the pesticides and the surrogates at concentrations ranging from 0.025 to $2.5 \mathrm{ng} / \mu \mathrm{L}$, while the internal standard is maintained at a constant concentration of $1 \mathrm{ng} / \mu \mathrm{L}$. The calibration solutions are made by adding the appropriate amount of standard solution $(10 \mathrm{ng} / \mu \mathrm{L})$ in $5-\mathrm{mL}$ volumetric flasks and bringing to volume with the dilute internal standard solution

7.10 Matrix-spike solutions - Two solutions, herbicide/ insecticides and fungicides, containing $2 \mathrm{ng} / \mu \mathrm{L}$ of the representative subset of pesticides are prepared by diluting $1 \mathrm{~mL}$ of herbicide/insecticide or fungicide stock solutions $(20 \mathrm{ng} / \mu \mathrm{L})$ into EtOAc in a $10 \mathrm{~mL}$ volumetric flask.

7.11 Surrogate-spike solution-Solution containing $2 \mathrm{ng} / \mu \mathrm{L}$ of surrogate is prepared by adding 0.2 or $0.4 \mathrm{~mL}$ of the concentrated surrogates (depending on if their initial concentration was 100 or $50 \mathrm{ng} / \mu \mathrm{L}$, respectively) into EtOAc in a $10-\mathrm{mL}$ volumetric flask.

\section{Sample Preparation Procedure for Sediment Samples}

The extraction of pesticides from sediment samples and the subsequent cleanup steps are outlined below:

\subsection{Sediment Sample Extraction}

8.1.1 Sample collection and storage — Collect bed-sediment or aqueous suspended-sediment samples by using methods that accurately represent the organic concentrations in the environmental matrix at a given location. Field-sampling procedures need to follow those typically used to collect samples for trace organic compound analyses (Ward and Harr, 1990; Radtke, 2005) and special procedures unique to pyrethroid (Hladik and others, 2009b). Samples are immediately chilled, and at the laboratory, they are stored by freezing to $-20^{\circ} \mathrm{C}$. A 6-month holding-time limit has been established from the date of sample collection to the date of sample extraction. All samples are thawed before analysis.

8.1.2 Accelerated Solvent Extraction-Turn on the ASE ${ }^{\circledR}$ 350; make sure the $\mathrm{ASE}^{\circledR}$ exhausts outside the laboratory. Soak the frits from the cap assembly in DCM for several minutes and place in caps. Rinse all stainless-steel vessels and caps with acetone and hexane before use. Place two prebaked GF/F filters in the bottom of each vessel. Start with wet (moist, not dried) sediment; if frozen, thaw the sediment overnight in the refrigerator. Prior to extraction, calculate the percentage moisture of the sediment. Weigh approximately $10.0 \mathrm{~g}$ dry weight of homogenized material into a precleaned mortar containing anhydrous sodium sulfate and mix until the sediment is mostly dry. Fill pre-labeled extraction vessel with mixture; add Ottawa sand to fill any dead space in cell. Add $50 \mu \mathrm{L}$ of $2 \mathrm{ng} / \mu \mathrm{L}$ surrogate solution. For matrix-spike samples, add $100 \mu \mathrm{L}$ of both $2 \mathrm{ng} / \mu \mathrm{L}$ herbicide/insecticide solutions and the fungicide matrix-spike solution. Cap the $\mathrm{ASE}^{\circledR}$ vessels tightly and place into the $\mathrm{ASE}^{\circledR}$ sample tray while transferring the label of the vessel to the appropriate glass collection vial in the collection tray. Fill the solvent reservoirs A and B with 100 percent DCM and manually rinse the $\mathrm{ASE}^{\circledR}$ three times prior to running. Extract the samples with 100 percent $\mathrm{DCM}$ and run the $\mathrm{ASE}^{\circledR}$ under the following conditions: pressure at 1,500 psi, temperature $100^{\circ} \mathrm{C}$ and heat for 5 minutes, and purge at 60 percent of the volume, for three cycles. For each sample, include a rinse from solvent reservoir B.

Once the $\mathrm{ASE}^{\circledR}$ is done running, remove glass collection vials. Set up glass funnels (with glass wool at bottom of funnel) with anhydrous sodium sulfate (about $30 \mathrm{~g}$ ). Open the extraction vessels and slowly decant the samples over sodium sulfate to remove the water and let the solvent 
flow into an appropriate collection vessel. Rinse the sodium sulfate two times with DCM (approximately $5 \mathrm{~mL}$ ), collecting the DCM in the collection vessel corresponding to the sample. Once rinsed, discard the sodium sulfate. Concentrate extracts under nitrogen to approximately $0.5 \mathrm{~mL}$ using the TurboVap ${ }^{\circledR}$. Filter out any particulates in the extract by transferring it to a concentrator tube through a syringe filter. Use DCM to rinse TurboVap ${ }^{\circledR}$ tube and syringe filter twice to minimize loss of extract. The extract is then exchanged into EtOAc and concentrated under nitrogen to less than $0.5 \mathrm{~mL}$ using the N-Evap.

\subsection{Sediment-Sample Removal of Matrix}

8.2.1 HPLC-GPC-The first cleanup step, done to primarily remove sulfur, is accomplished with HPLC-GPC. Turn on pump and UV/Vis lamp (254-nm absorbance wavelength) and allow them to warm up for $30 \mathrm{~min}$ (flow rate $=1.0 \mathrm{~mL} / \mathrm{min}$ ). Make sure EtOAc reservoir is full. To determine the collection window (time interval), inject $200 \mu \mathrm{L}$ of each matrix-spike solution $(2 \mathrm{ng} / \mu \mathrm{L})$. Immediately following the injection, start the stopwatch. Once the ultraviolet (UV) absorbance starts to increase, note the time. When the absorbance drops back to approximately zero, note the time again; this will give you a collection window. To make sure all the compounds have had sufficient time to exit the system, give the window a 30-s duration on each side. Usually the collection window ranges from 7-15 min. Rinse the injector loop between samples with EtOAc. After determining the collection window, inject the entire sample onto the GPC. Immediately after the sample is injected, start the stopwatch. Place a $15-\mathrm{mL}$ graduated test tube in the collection beaker; at the start of the collection window, remove the waste hose and place in test tube to collect compounds. At the end of the collection window, re-attach the waste hose and allow solvent to pump through the GPC for another 30-35 min (sulfur should come out $\sim 20$ min after the end of your collection window). Reduce the collected sample to $2.0 \mathrm{~mL}$ using the N-Evap. Split the samples equally into two 1.0-mL aliquots; half the sample will go through SPE cleanup and the other will go through Florisi $^{\mathbb{R}}{ }^{\text {cleanup. }}$

8.2.2 SPE cleanup (herbicides/insecticides)—The first step is to exchange the EtOAc fraction into DCM: concentrate this fraction under nitrogen to less than $0.2 \mathrm{~mL}$ on the N-Evap, add $1.0 \mathrm{~mL}$ of DCM, and shake to mix. Repeat this solvent-exchange again, then concentrate the sample back down to $1.0 \mathrm{~mL}$. Once the fraction is in mostly DCM (DCM is more volatile than EtOAc, so not all the EtOAc can be removed), assemble sets of cartridges with one carbon SPE cartridge stacked onto one alumina SPE cartridge on a vacuum manifold. Clean cartridges with three column volumes of DCM. IMPORTANT: do not allow cartridges to go dry. After the cartridges are cleaned, place $15-\mathrm{mL}$ glass concentrator tubes in the manifold rack. For each of the samples, add the ASE® extract to the top of the carbon cartridge (of the cartridge set) that corresponds to the correctly labeled collection tube and then rinse the concentrator tube with a small volume of DCM (less than $0.5 \mathrm{~mL}$ ) to remove any remaining extract. Elute a portion of the analytes from the cartridges with $10 \mathrm{~mL}$ of DCM at $\sim 1-2$ drop/s. Remove the carbon cartridge and elute only the alumina SPE cartridge with $10 \mathrm{~mL}$ of 50 percent DCM:EtOAc; collect the eluent from the alumina cartridge in a fresh concentrator tube. Reduce the DCM and DCM:EtOAc fractions using the N-evap to less than $0.5 \mathrm{~mL}$, combine into one fraction and reduce to $0.5 \mathrm{~mL}$, exchange two times to EtOAc. Reduce the resulting sample to $0.2 \mathrm{~mL}$, add $20 \mu \mathrm{L}$ of dilute ISTD dilute solution $(1 \mathrm{ng} / \mu \mathrm{L})$, and transfer to GC/MS autosampler vials. The sample extracts are stored in a freezer at $-20^{\circ} \mathrm{C}$ until analysis.

8.2.3 Florisil ${ }^{\circledR}$ cleanup (fungicides) — Exchange the Florisil ${ }^{\circledR}$ fraction (ASE ${ }^{\circledR}$ extract intended for Florisil cleanup) into hexane by concentrating the previously split fraction (from 8.2.1) to less than $0.2 \mathrm{~mL}$ under nitrogen using the N-Evap, then adding $1.0 \mathrm{~mL}$ hexane, and shaking to mix. Repeat this solvent-exchange step, then concentrate the sample back down to $1.0 \mathrm{~mL}$; at this point, the sample extract collected into the concentrator tube will be mostly hexane (because hexane is more volatile than EtOAc, not all the EtOAc can be removed). Prepare Florisil ${ }^{\circledR}$ columns by weighing out $10.0 \pm$ $0.02 \mathrm{~g}$ into a precleaned $200 \mathrm{~mL}$ glass column equipped with a stopcock and glass wool in the bottom. Add a layer approximately $1-\mathrm{cm}$ thick of sodium sulfate to the top of the Florisil ${ }^{\circledR}$ and rinse with $70 \mathrm{~mL}$ of hexane, taking care to close the stopcock when approximately $1 \mathrm{~cm}$ of hexane remains above the top of the sodium-sulfate sorbent. Introduce the sample-extract fraction onto the column with a glass pipette; rinse the concentrator tube that contained the extract twice with hexane. The compounds of interest are eluted with $20 \mathrm{~mL}$ of 20 percent DCM in hexane followed by $100 \mathrm{~mL}$ of 50 percent EtOAc in hexane collected in the same flask. Following Florisil ${ }^{\circledR}$ cleanup, reduce the sample eluents to $0.5 \mathrm{~mL}$, exchange into EtOAc, then further reduce to $0.2 \mathrm{~mL}$, add $20 \mu \mathrm{L}$ of dilute ISTD, and transfer to GC/MS autosampler vials. The sample extracts are stored in a freezer at $-20^{\circ} \mathrm{C}$ until analysis. 


\section{Instrument Calibration and Analysis Procedures}

Aliquots of the samples are injected and the compounds separated and detected by using an Agilent 7890A GC and detected on a Agilent 5975C Inert XL EI/CI MSD system with a DB-5MS analytical column $(30 \mathrm{~m} \times 0.25 \mathrm{~mm} \times 0.25 \mu \mathrm{m})$.

$9.1 \mathrm{GC} / \mathrm{MS}$ performance evaluation-Before sample analysis, a new injector insert and septa are installed on the GC, and approximately $3-5 \mathrm{~cm}$ is removed from the injector end of the analytical column to maintain column performance with sediment samples. The MS is checked for potential air and water leaks (mass to charge ratio, or $m / z$ of 28 and 32, and 18 , respectively) prior to beginning the analytical batch. The MS calibration standard, perfluorotributylamine (PFTBA), is used to optimize mass resolution and calibrate representative analyte masses after instrument maintenance. The performance of the GC/MS is evaluated prior to each sample batch by injecting $1 \mu \mathrm{L}$ of a calibration solution $(0.5 \mathrm{ng} / \mu \mathrm{L}$ of either herbicide/insecticide solution or the fungicide solution from 7.9) and assessing retention times, peak areas, and product ion abundances and ratios (using the conditions described below).

9.2 GC/MS Injections for Analysis - The GC/MS conditions for the analysis of pesticides are listed below.

9.2.1 GC conditions: Injections of $1 \mu \mathrm{L}$ are made with the injector at $275^{\circ} \mathrm{C}$ in pulsed splitless mode with a $50 \mathrm{psi}$ pressure pulse for $1 \mathrm{~min}$. The flow of He through a GC column is set at $1.2 \mathrm{~mL} / \mathrm{min}$. The herbicide/insecticide oven program is $80^{\circ} \mathrm{C}$ for $1.0 \mathrm{~min}$, ramp at $10^{\circ} \mathrm{C} / \mathrm{min}$ until $120^{\circ} \mathrm{C}$, then ramp at $3^{\circ} \mathrm{C} / \mathrm{min}$ until $200^{\circ} \mathrm{C}$ and hold for 5 minutes, ramp at $3^{\circ} \mathrm{C} / \mathrm{min}$ until $219^{\circ} \mathrm{C}$, and a final ramp at $10^{\circ} \mathrm{C} / \mathrm{min}$ until $300^{\circ} \mathrm{C}$ and hold for 10 minutes. The fungicide oven program is $80^{\circ} \mathrm{C}$ for $0.5 \mathrm{~min}$, ramp at $10^{\circ} \mathrm{C} / \mathrm{min}$ until $180^{\circ} \mathrm{C}$, then ramp at $5^{\circ} \mathrm{C} / \mathrm{min}$ until $220^{\circ} \mathrm{C}$ and hold for 1 minute, ramp at $4^{\circ} \mathrm{C} / \mathrm{min}$ until $280^{\circ} \mathrm{C}$ and hold for 1 minute, and a final ramp at $10^{\circ} \mathrm{C} / \mathrm{min}$ until $300^{\circ} \mathrm{C}$ and hold for 10 minutes.

9.2.2 MS Conditions: the transfer line from the GC to the MS is set at $280^{\circ} \mathrm{C}$, the quadrupole is at $150^{\circ} \mathrm{C}$, and the MS ion source is set at $230^{\circ} \mathrm{C}$. The MS is operated in electron-ionization (EI) mode. Data is collected in the selected-ion-monitoring (SIM) mode; details of the retention times, quantitation ions, and qualification ions for the SIM windows are given in table 2.

9.3 Instrument Calibration-The GC/MS is calibrated with each new sample batch. A minimum of five and up to seven calibration standards are run. The calibration range for GC/MS is 0.025 to $2.5 \mathrm{ng} / \mu \mathrm{L}$. These calibration standards correspond to environmental sample concentrations of 0.5 to $50 \mu \mathrm{g} / \mathrm{kg}$ for sediment.

9.4 Data acquisition and processing-Chemstation version E.02.00 software is used to acquire data and Agilent Mass Hunter version B.04.00 software is used to calibrate and quantify the responses of the pesticides. Pesticides with multiple peaks are summed for quantification. Calibration and quantification are described in more detail in section 11.

Table 2. Retention times, quantitation ions and confirmation ions for pesticides analyzed by GC/MS.

[Samples are split into an herbicide/insecticide group (carbon/alumina SPE cleanup) and a fungicide group (Florisil cleanup; the compounds noted with an asterisk are not actually fungicides but work with the Florisil cleanup). Abbreviations/Acronyms: GC/MS, gas chromatography with mass spectrometry; m/z, mass-to-charge ratio]

\begin{tabular}{lccl}
\hline \multicolumn{1}{c}{ Herbicides/Insecticides } & $\begin{array}{c}\text { Retention } \\
\text { time } \\
\text { (minute) }\end{array}$ & $\begin{array}{c}\text { Quantitation Confirmation } \\
\text { ion } \\
\text { (m/z) }\end{array}$ & $\begin{array}{c}\text { (m/z) } \\
\text { ions }\end{array}$ \\
\hline EPTC & 9.2 & 128 & 189,86 \\
3,5-Dichloroaniline & 10.4 & 161 & 163 \\
Butylate & 11.0 & 146 & 156 \\
3,4-Dichloroaniline & 11.1 & 161 & 163 \\
Pebulate & 11.9 & 128 & 161 \\
Molinate & 14.1 & 126 & 187,83 \\
Cycloate & 17.1 & 83 & 154 \\
Ethalfluralin & 17.8 & 276 & $333,316,292$ \\
Trifluralin & 18.4 & 306 & 316,264 \\
Benfluralin (Benefin) & 18.5 & 292 & 276,264 \\
2-Chloro-2,6- & 19.3 & 176 & 225,147 \\
$\quad$ Diethylacetanilide & & & \\
Pentachloroanisole & 19.5 & 265 & 280,237 \\
Fenpyroximate & 20.4 & 213 & 198,142 \\
Carbofuran & 20.5 & 164 & 149
\end{tabular}

\begin{tabular}{lccl}
\hline Herbicides/Insecticides & $\begin{array}{c}\text { Retention } \\
\text { time } \\
\text { (minute) }\end{array}$ & $\begin{array}{c}\text { Quantitation Confirmation } \\
\text { ion } \\
(\mathbf{m} / \mathbf{z})\end{array}$ & $\begin{array}{c}\text { ions } \\
(\mathbf{m} / \mathbf{z})\end{array}$ \\
\hline Simazine & 20.6 & 201 & 186,173 \\
Clomazone & 20.9 & 125 & 204 \\
Atrazine & 21.0 & 200 & 215,173 \\
Prometon & 21.1 & 210 & 225,125 \\
Propyzamide & 21.9 & 173 & 255,175 \\
Pronamide (Propyzamide) & 22.0 & 173 & $255,240,145$ \\
Diazinon & 22.3 & 179 & 304,137 \\
Triallate & 23.1 & 169 & $268,142,128$ \\
Tefluthrin & 23.4 & 177 & 197,141 \\
Tebupirimfos & 23.7 & 261 & $318,234,152$ \\
Propanil & 24.9 & 161 & 217,163 \\
Methyl parathion & 25.2 & 125 & 263,109 \\
Alachlor & 25.3 & 160 & 188,146 \\
Carbaryl & 25.6 & 144 & 115 \\
Fipronil desulfinyl & 25.6 & 388 & 390,333
\end{tabular}


Table 2. Retention times, quantitation ions and confirmation ions for pesticides analyzed by GC/MS.-Continued

[Samples are split into an herbicide/insecticide group (carbon/alumina SPE cleanup) and a fungicide group (Florisil cleanup; the compounds noted with an asterisk are not actually fungicides but work with the Florisil cleanup). Abbreviations/Acronyms: GC/MS, gas chromatography with mass spectrometry; m/z, mass-to-charge ratio]

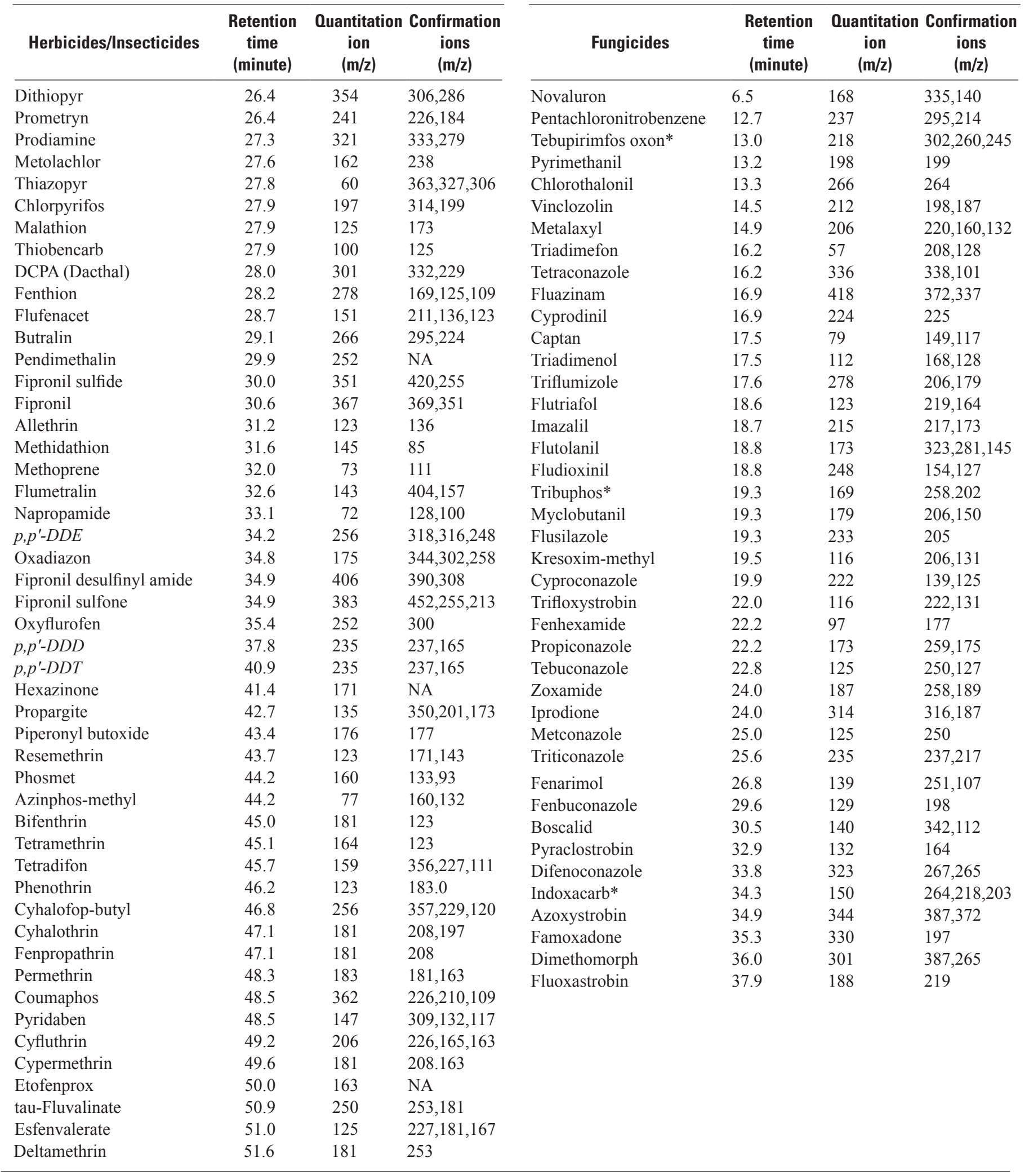




\section{Quality Assurance and Quality Control}

The quality-assurance (QA) and quality-control (QC) program primarily consists of internal checks on precision and accuracy of analytical results. Laboratory QC data from continuous calibration verification (CCV), laboratoryblank and matrix-spiked samples, and internal and surrogate standards are used by the analyst to determine if corrective actions are needed or if sample concentrations are not accurately reported.

10.1 Field sampling-Accuracy of sample handling in the field is monitored when field blanks and field replicates are included for analysis by the laboratory. Each environmental sample or QC sample is handled separately for proper data determination by the analyst.

10.2 Continuous calibration verification ( $\mathrm{CCV}$ ) - The $\mathrm{CCV}$ solutions, which are standard solutions of pesticides prepared in a manner similar to the calibration standards, are used to monitor the method stability in comparison to the initial calibration curve. The CCV control limits are established at \pm 25 percent of the expected concentration for each pyrethroid. If a CCV fails the QC criteria, the affected samples are reanalyzed.

10.3 Internal standards - Internal standards are added to correct quantitative differences in extract volume as well as to compensate for differences in extract volume injected. Internal standards are also used to monitor instrument conditions, such as extract injection errors, retention time shifts, or instrument abnormalities or malfunctions.

10.4 Laboratory blank - A laboratory blank is an aliquot of baked sodium sulfate used to monitor the entire sample preparation and analytical procedure for possible laboratory contamination. The laboratory blank is considered acceptable when a compound is either undetected or is detected at or below one-third of the MDL. Laboratory blanks are analyzed for a minimum of 1 per every 20 samples. If a compound is detected in the laboratory blank above the MDL, no further samples are run until the source of the contamination is identified and eliminated.

10.5 Laboratory matrix spike-The laboratory matrix spike is an aliquot of an environmental sample to which known quantities of the method analytes are added in the laboratory. The laboratory matrix spike is analyzed exactly like a regular sample and is used to determine whether the sample matrix contributes bias to the analytical results and, therefore, the degree the method is successful in recovering the target analytes. The background concentration of the analytes in the sample matrix, if any are present, must be determined in a separate aliquot so that the values in the laboratory matrix spike can be corrected for their presence, and the percentage recovery calculated.

\subsubsection{Percent recovery calculation:}

Calculate the percent recovery $(\% R)$ for each selected compound as follows:

$$
\% R=\left[\begin{array}{c}
\left.\mathrm{C}_{\text {matrix spike }}-\mathrm{C}_{\text {background }}\right] / \\
\mathrm{C}_{\text {expected }} * 100 \text { percent }
\end{array}\right.
$$

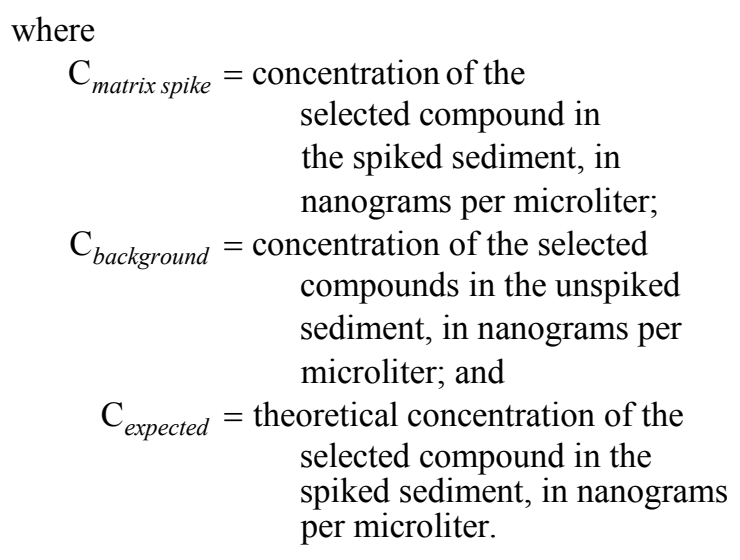
$\mathrm{C}_{\text {expected }}=$ theoretical concentration of the selected compound in the spiked sediment, in nanograms per microliter.

Laboratory matrix spikes are analyzed for a minimum of 1 per every 20 samples, or more frequently if a batch includes new or usual sample matrixes. If a matrix-spike recovery is below 70 percent, the sample set is evaluated for potential issues; if these issues cannot be rectified, the sample-set results are thrown out.

10.6 Laboratory matrix-spike duplicate-The laboratory matrix-spike duplicate is prepared and analyzed in the same manner as the laboratory matrix spike and is compared with the laboratory matrix spike to determine method variability. Laboratory matrix-spike duplicates are analyzed for a minimum of 1 per every 30 samples if the study calls for laboratory matrix-spike duplicates. The matrix spike and matrix-spike duplicate must have a RPD less than 25 percent to be considered acceptable.

10.7 Laboratory replicate - The laboratory replicate is a sample split into fractions for multiple analyses. Laboratory replicates are analyzed for a minimum of 1 per every 20 samples.

10.8 Surrogate standards - Surrogate standards are compounds similar in physical and chemical properties to the target analytes but which are not expected to be present in the environment. Surrogate standards are added to each environmental and quality-assurance/quality-control (QA/QC) sample and are used to monitor matrix effects and overall method performance. Their recoveries are not used to correct compound concentrations in environmental samples. If surrogate recoveries are less than 70 percent or greater than 130 percent, the sample is either thrown out (if there is no more sample material) or re-extracted and analyzed (if more sample material is available). 
10.9 Solvent Blank-A solvent blank is an injection of solvent (in this case EtOAc) onto the GC/MS to determine if there is carryover of target analytes between sample injections. If analytes are detected in the solvent blank, the source of the carryover is determined, and the sample set is reanalyzed.

10.10 Instrumental analysis quality control - An example of a typical analytical sequence used for this method is listed in table 3. Sample extracts (including field blanks, replicates, matrix spikes, and laboratory spikes) are analyzed in an instrument sequence to provide additional information if performance criteria are not met.

Table 3. Example analytical sequence for use in determining pesticides in sediments.

["Samples" listed in column three include environmental samples, blanks (field and laboratory), replicates (field and laboratory), and matrix spikes and matrix-spike duplicates. Abbreviations/Acronyms: EtOAc, ethyl acetate; $\mathrm{QC}$, quality control; $\mathrm{CCV}$, continuing calibration verification]

\begin{tabular}{|c|c|c|}
\hline $\begin{array}{l}\text { Sample } \\
\text { number }\end{array}$ & $\begin{array}{c}\text { Vial } \\
\text { number }\end{array}$ & Sample type \\
\hline 1 & 1 & Solvent blank (EtOAc) \\
\hline 2 & 2 & Calibration standard 1 \\
\hline 3 & 3 & Calibration standard 2 \\
\hline 4 & 4 & Calibration standard 3 \\
\hline 5 & 5 & Calibration standard 4 \\
\hline 6 & 6 & Calibration standard 5 \\
\hline 7 & 7 & Calibration standard 6 \\
\hline 8 & 8 & Calibration standard 7 \\
\hline 9 & 1 & Solvent blank (EtOAc) \\
\hline 10 & 9 & Sample 1 \\
\hline 11 & 10 & Sample 2 \\
\hline 12 & 11 & Sample 3 \\
\hline 13 & 12 & Sample 4 \\
\hline 14 & 13 & Sample 5 \\
\hline 15 & 14 & Sample 6 or QC (lab blank) \\
\hline 16 & 6 & $\mathrm{CCV}$ \\
\hline 17 & 1 & Solvent blank (EtOAc) \\
\hline 18 & 15 & Sample 7 \\
\hline 19 & 16 & Sample 8 \\
\hline 20 & 17 & Sample 9 or QC (matrix spike) \\
\hline 21 & 18 & Sample 10 \\
\hline 22 & 19 & Sample 11 \\
\hline 23 & 20 & Sample 12 \\
\hline 24 & 6 & $\mathrm{CCV}$ \\
\hline 25 & 1 & Solvent blank (EtOAc) \\
\hline 26 & 21 & Sample 13 \\
\hline 27 & 22 & Sample 14 \\
\hline 28 & 23 & Sample 15 \\
\hline 29 & 24 & Sample 16 \\
\hline 30 & 25 & Sample 17 or QC (replicate) \\
\hline 31 & 26 & Sample18 \\
\hline 32 & 6 & $\mathrm{CCV}$ \\
\hline 33 & 1 & Solvent blank (EtOAc) \\
\hline
\end{tabular}

\section{Calculation of Results}

11.1 Qualitative identification - Before quantitative results are reported, each compound first needs to meet qualitative criteria. Identification and quantification of compounds are performed on the raw data files using the Mass Hunter analysis package. A compound is not considered to be identified correctly unless the correct quantitation ion(s) of the peak are detected, the relative ratios of the confirmation ions are within \pm 25 percent of the average ratio obtained from the calibration samples, and the relative retention time of the peak is within 5 percent of the expected retention time.

11.2 Quantification - Five- to six-point calibration curves are constructed by using linear regression from the calibration standards (which standards are used depends on sample concentrations and instrument performance). Only after the compound has passed qualitative criteria is the concentration calculated according to a calibration curve used to establish the best fit between the calibration points. The correlation coefficient for each standard curve has to be greater than or equal to 0.99 to be accepted. The response factor for each compound is calculated from the calibration curve.

\subsubsection{Response-factor calculation}

Calculate the response factor $(R F)$ for each selected compound as follows:

$$
R F=\frac{C_{c} \times A_{i}}{C_{i} \times A_{c}}
$$

where

$$
\begin{gathered}
C_{c}=\begin{array}{c}
\text { concentration of the selected compound, } \\
\text { in nanograms per microliter; }
\end{array} \\
A_{i}=\begin{array}{l}
\text { area of peak of the quantitation ion for the } \\
\text { internal standard; }
\end{array} \\
C_{i}=\begin{array}{c}
\text { concentration of the internal standard, in } \\
\text { nanograms per microliter; and }
\end{array} \\
A_{c}=\begin{array}{l}
\text { area of peak of the quantitation ion for } \\
\text { the selected compound. }
\end{array}
\end{gathered}
$$


11.3 Calculations - If a selected compound has passed the qualitative identification criteria and the area under the peak(s) for the quantitation ion(s) for that compound has been properly integrated, the concentration in the sample is calculated as follows:

\subsubsection{Sediment-Sample Calculations}

Calculate the dry weight of sediment extracted, in grams:

$$
W_{d}=W_{w}[(100-\% \text { moisture }) / 100
$$

where

$W_{d}=$ dry weight of sediment, in grams; and

$W_{w}=$ wet weight of sediment, in grams.

Calculate sample-extract concentrations, $E$, for each compound:

$$
E=\left(A_{c} / A_{i}\right) \times(R F) \times C_{i}
$$

where

$$
\begin{gathered}
E=\begin{array}{c}
\text { concentration of the selected compound } \\
\text { in the sample extract, in nanograms } \\
\text { per microliter; }
\end{array} \\
A_{c}=\begin{array}{c}
\text { area of peak of the quantitation ion for } \\
\text { the selecetd compound; }
\end{array} \\
A_{i}=\begin{array}{c}
\text { area of peak of the quantitation ion for } \\
\text { the internal standard; }
\end{array} \\
R F=\begin{array}{c}
\text { response factor calculated in equation } 1 ; \\
\text { and }
\end{array} \\
C_{i}=\begin{array}{c}
\text { concentration of the internal standard, in } \\
\text { nanograms per microliter. }
\end{array}
\end{gathered}
$$

Calculate sample concentrations, $C_{s}$, in micrograms per kilogram (which is equal to nanograms per gram), for each compound:

$$
C_{s}=(E \times 200 \mu \mathrm{L}) / W_{s}
$$

where

$$
\begin{gathered}
E=\begin{array}{c}
\text { concentration of the selected compound } \\
\text { in the sample extract, in nanograms } \\
\text { per microliter; and }
\end{array} \\
W_{s}=\text { dry weight of sediment, in grams. }
\end{gathered}
$$

\section{Reporting of Data Results}

Pesticides are reported in concentrations from 0.5 to $50 \mu \mathrm{g} / \mathrm{kg}$ for sediment. If the concentration is greater than $50 \mu \mathrm{g} / \mathrm{kg}$, a portion of the original sample extract is diluted appropriately with EtOAc, prepared with internal standard, and reanalyzed.

\section{Method Performance}

Initial method performance was evaluated for recovery using sediment collected from a northern California agricultural drain; this drain had a "typical" organic carbon concentration (1.5 percent) and had low background pesticide concentrations. Samples were spiked at $40 \mu \mathrm{g} / \mathrm{kg}$ (dry weight) and all compound recoveries were greater than 70 percent (an unspiked sediment sample was also run to determine if any of the pesticides were natively present in the sediment; data not shown). Additional method-performance metrics, including method recovery, variability, and MDLs, were determined using several samples of two sediments with different levels of percent organic carbon (described below) that had been collected and processed in the same manner as environmental samples.

13.1 Method recovery and variability - Pesticide recoveries and analytical variability were determined by comparing seven spiked samples with one another. These recoveries were determined in two different sediments; one from a northern California agricultural creek with 1.5 percent organic carbon and another from a central California estuary with 3.7 percent organic carbon. The northern California agricultural drain had a "typical" organic carbon percentage; the central California estuary had a higher organic carbon percentage to represent a more complex sediment matrix. Pesticides were spiked onto sediment matrices at $10 \mu \mathrm{g} / \mathrm{kg}$ by adding $100 \mathrm{ng}$ of each compound per $10 \mathrm{~g}$ (dry weight) of sediment. Corresponding unspiked sediment samples were run to determine if any of the pesticides were present in the sediment before spiking; both sediments had low background pesticide concentrations. The mean recoveries for the two sediment matrixes are shown in table 4; the recoveries for pesticides included in the previous method were similar. The agricultural drain sediment had recoveries ranging from 81 to 101 percent, with relative standard deviations (RSDs) of 2 to 12 percent; the estuary sediment had recoveries of 75 to 102 percent (RSDs of 3 to 13 percent). Recoveries were good for both the "typical" sediment and the sediment with a higher percent organic carbon. Increased organic carbon can interfere with the recoveries of the pesticides of interest, and in sediments with a higher percent organic carbon, additional matrix spikes may be needed to determine the extent of potential interferences.

13.2 Method detection limit (MDL) - The MDL is defined as the minimum concentration of a substance that can be measured and reported with 99 percent confidence that the compound concentration is greater than zero (U.S. Environmental Protection Agency, 1997). Initial MDLs were determined according to the procedure outlined by the USEPA in 40 CFR 136, Appendix B, assuming a 10-g (dry weight) sediment sample size. 
The MDL was calculated according to the equation

$$
M D L=S \times t_{(n-1,1-\alpha=0.99)}
$$

where

$$
\begin{gathered}
S=\text { standard deviation of replicate } \\
\text { analyses, in micrograms per } \\
\text { kilogram, at the lowest spike } \\
\text { concentration; } \\
n=\text { number of replicate analyses; and } \\
t_{(n-1,1-\alpha=0.99)}=\begin{array}{l}
\text { Student's t-value for the 99-percent } \\
\text { confidence level with } n-1 \\
\text { degrees of freedom. }
\end{array}
\end{gathered}
$$

Following the USEPA procedure, seven replicate samples were fortified with compounds at concentrations two to five times the estimated MDL. This concentration range was used to calculate initial MDLs for the pesticides.

The MDLs for the GC/MS method are 0.6 to $3.1 \mu \mathrm{g} / \mathrm{kg}$ for the agricultural creek sediment and 0.8 to $3.4 \mu \mathrm{g} / \mathrm{kg}$ for the estuary sediment (table 4$)$. The percent organic carbon was higher for the estuary (3.7 percent) than the agricultural drain (1.5 percent), but the MDLs were similar. Higher organic carbon content can lead to more co-extracted matrix interferences that could increase the MDLs, but this method

\begin{tabular}{|c|c|c|c|c|c|c|}
\hline \multirow[t]{2}{*}{ Herbicides/Insecticides } & \multicolumn{3}{|c|}{$\begin{array}{l}\text { Northern California } \\
\text { agricultural drain sediment } \\
\text { (1.5 percent organic carbon) }\end{array}$} & \multicolumn{3}{|c|}{$\begin{array}{c}\text { Central California } \\
\text { estuary sediment } \\
\text { (3.7 percent organic carbon) }\end{array}$} \\
\hline & $\begin{array}{l}\text { Percent } \\
\text { recovery }\end{array}$ & $\begin{array}{c}\text { Percent } \\
\text { RSD }\end{array}$ & $\begin{array}{c}\text { MDL } \\
(\mu \mathrm{g} / \mathbf{k g})\end{array}$ & $\begin{array}{l}\text { Percent } \\
\text { recovery }\end{array}$ & $\begin{array}{c}\text { Percent } \\
\text { RSD }\end{array}$ & $\begin{array}{c}\text { MDL } \\
(\mu \mathrm{g} / \mathrm{kg})\end{array}$ \\
\hline 2-Chloro-2,6-Diethylacetanilide & 96.7 & 4.2 & 1.3 & 88.9 & 5.2 & 1.5 \\
\hline 3,4-Dichloroaniline & 80.5 & 5.2 & 1.3 & 77.3 & 7.2 & 1.8 \\
\hline 3,5-Dichloroaniline & 85.1 & 5.6 & 1.5 & 84.5 & 6.7 & 1.8 \\
\hline Alachlor & 95.5 & 1.9 & 0.6 & 92.3 & 3.7 & 1.1 \\
\hline Allethrin & 98.9 & 5.5 & 1.7 & 95.9 & 6.2 & 1.9 \\
\hline Atrazine & 86.7 & 5.4 & 1.5 & 87.4 & 6.2 & 1.7 \\
\hline Azinphos-methyl & 94.2 & 5.7 & 1.7 & 93.4 & 5.8 & 1.7 \\
\hline Benfluralin (Benefin) & 93.7 & 5.7 & 1.7 & 92.6 & 6.9 & 2.0 \\
\hline Bifenthrin & 99.3 & 2.0 & 0.6 & 96.0 & 2.6 & 0.8 \\
\hline Butralin & 95.8 & 5.3 & 1.6 & 92.4 & 5.9 & 1.7 \\
\hline Butylate & 88.2 & 4.6 & 1.3 & 81.5 & 5.7 & 1.5 \\
\hline Carbaryl & 97.3 & 3.9 & 1.2 & 96.0 & 5.0 & 1.5 \\
\hline Carbofuran & 88.3 & 4.4 & 1.2 & 93.0 & 5.2 & 1.5 \\
\hline Chlorpyrifos & 93.0 & 3.1 & 0.9 & 93.0 & 4.4 & 1.3 \\
\hline Clomazone & 94.9 & 6.6 & 2.0 & 91.2 & 7.4 & 2.1 \\
\hline Coumaphos & 94.2 & 4.0 & 1.2 & 87.6 & 5.0 & 1.4 \\
\hline Cyhalofop-butyl & 97.3 & 2.6 & 0.8 & 95.9 & 3.1 & 0.9 \\
\hline Cycloate & 90.1 & 2.8 & 0.8 & 88.2 & 4.2 & 1.2 \\
\hline Cyfluthrin & 93.9 & 4.4 & 1.3 & 94.6 & 4.5 & 1.3 \\
\hline Cyhalothrin & 96.7 & 2.3 & 0.7 & 97.5 & 2.7 & 0.8 \\
\hline Cypermethrin & 93.9 & 4.2 & 1.2 & 96.5 & 4.7 & 1.4 \\
\hline DCPA (Dacthal) & 99.5 & 5.5 & 1.7 & 99.3 & 5.8 & 1.8 \\
\hline Deltamethrin & 94.3 & 4.2 & 1.3 & 97.3 & 4.4 & 1.3 \\
\hline Diazinon & 86.9 & 5.8 & 1.6 & 87.5 & 6.9 & 1.9 \\
\hline Dithiopyr & 84.8 & 4.7 & 1.3 & 81.9 & 5.4 & 1.4 \\
\hline EPTC & 82.2 & 3.1 & 0.8 & 91.8 & 4.0 & 1.1 \\
\hline Esfenvalerate & 93.0 & 3.4 & 1.0 & 94.0 & 4.0 & 1.2 \\
\hline Ethalfluralin & 90.5 & 4.1 & 1.2 & 93.0 & 4.7 & 1.4 \\
\hline Etofenprox & 96.1 & 3.3 & 1.0 & 93.6 & 4.4 & 1.3 \\
\hline Fenpropathrin & 95.6 & 3.5 & 1.0 & 96.1 & 4.0 & 1.2 \\
\hline Fenpyroximate & 83.1 & 7.2 & 1.9 & 92.4 & 7.5 & 2.2 \\
\hline
\end{tabular}
is robust for higher organic carbon concentrations; prior studies have analyzed sediment samples with up to 36 percent organic carbon.

Table 4. Summary of method recovery and variability (expressed as mean percent recovery and relative standard deviation) and method detection limits determined from sets of 7 spiked samples of two different sediment matrixes.

[Herbicides/Insecticides indicates carbon/alumina-SPE cleanup. Fungicides indicates Florisil cleanup. Compounds noted with an asterisk are non-fungicides that are amenable to Florisil cleanup. Abbreviations/Acronyms: RSD, relative standard deviation; MDL, method detection limit; $\mu \mathrm{g} / \mathrm{kg}$, microgram per kilogram] 
Table 4. Summary of method recovery and variability (expressed as mean percent recovery and relative standard deviation) and method detection limits determined from sets of 7 spiked samples of two different sediment matrixes.Continued

[Herbicides/Insecticides indicates carbon/alumina-SPE cleanup. Fungicides indicates Florisil cleanup. Compounds noted with an asterisk are non-fungicides that are amenable to Florisil cleanup. Abbreviations/Acronyms: RSD, relative standard deviation; MDL, method detection limit; $\mu \mathrm{g} / \mathrm{kg}$, microgram per kilogram]

\begin{tabular}{|c|c|c|c|c|c|c|}
\hline \multirow[t]{2}{*}{ Herbicides/Insecticides } & \multicolumn{3}{|c|}{$\begin{array}{l}\text { Northern California } \\
\text { agricultural drain sediment } \\
\text { (1.5 percent organic carbon) }\end{array}$} & \multicolumn{3}{|c|}{$\begin{array}{c}\text { Central California } \\
\text { estuary sediment } \\
\text { (3.7 percent organic carbon) }\end{array}$} \\
\hline & $\begin{array}{l}\text { Percent } \\
\text { recovery }\end{array}$ & $\begin{array}{c}\text { Percent } \\
\text { RSD }\end{array}$ & $\begin{array}{c}\text { MDL } \\
(\mu \mathrm{g} / \mathrm{kg})\end{array}$ & $\begin{array}{l}\text { Percent } \\
\text { recovery }\end{array}$ & $\begin{array}{l}\text { Percent } \\
\text { RSD }\end{array}$ & $\begin{array}{c}\text { MDL } \\
(\mu \mathrm{g} / \mathrm{kg})\end{array}$ \\
\hline Fenthion & 96.7 & 6.6 & 2.0 & 87.6 & 8.3 & 2.3 \\
\hline Fipronil & 94.3 & 5.4 & 1.6 & 97.9 & 5.8 & 1.8 \\
\hline Fipronil desulfinyl & 92.2 & 6.1 & 1.8 & 96.4 & 7.1 & 2.1 \\
\hline Fipronil desulfinyl amide & 83.4 & 7.5 & 2.0 & 77.9 & 8.2 & 2.0 \\
\hline Fipronil sulfide & 93.2 & 5.0 & 1.5 & 95.8 & 5.3 & 1.6 \\
\hline Fipronil sulfone & 98.3 & 3.1 & 1.0 & 98.1 & 4.0 & 1.2 \\
\hline Flufenacet & 96.0 & 3.3 & 1.0 & 94.1 & 3.9 & 1.2 \\
\hline Flumetralin & 95.7 & 4.1 & 1.2 & 92.3 & 5.4 & 1.6 \\
\hline Hexazinone & 94.0 & 3.1 & 0.9 & 86.0 & 4.6 & 1.3 \\
\hline Malathion & 93.1 & 3.3 & 1.0 & 94.0 & 4.5 & 1.3 \\
\hline Methidathion & 99.3 & 5.7 & 1.8 & 84.3 & 6.9 & 1.8 \\
\hline Methoprene & 96.3 & 5.4 & 1.6 & 86.9 & 6.8 & 1.9 \\
\hline Methyl parathion & 92.4 & 3.8 & 1.1 & 89.9 & 5.1 & 1.5 \\
\hline Metolachlor & 96.5 & 2.4 & 0.7 & 90.1 & 4.5 & 1.3 \\
\hline Molinate & 91.1 & 3.4 & 1.0 & 79.7 & 5.4 & 1.4 \\
\hline Napropamide & 98.5 & 2.8 & 0.9 & 92.2 & 3.7 & 1.1 \\
\hline Oxadiazon & 99.2 & 4.4 & 1.4 & 91.1 & 5.3 & 1.5 \\
\hline Oxyflurofen & 100.7 & 6.0 & 1.9 & 96.2 & 7.5 & 2.3 \\
\hline$p, p^{\prime}-D D D$ & 95.4 & 3.3 & 1.0 & 97.9 & 4.2 & 1.3 \\
\hline$p, p^{\prime}-D D E$ & 99.3 & 3.1 & 1.0 & 96.9 & 4.1 & 1.2 \\
\hline$p, p^{\prime}-D D T$ & 93.9 & 2.8 & 0.8 & 96.2 & 3.7 & 1.1 \\
\hline Pentachloroanisole & 90.4 & 3.9 & 1.1 & 82.2 & 5.1 & 1.3 \\
\hline Pebulate & 87.7 & 3.3 & 0.9 & 82.2 & 3.8 & 1.0 \\
\hline Pendimethalin & 94.3 & 2.7 & 0.8 & 95.5 & 3.7 & 1.1 \\
\hline Permethrin & 94.1 & 3.1 & 0.9 & 97.5 & 3.5 & 1.1 \\
\hline Phenothrin & 95.5 & 3.0 & 0.9 & 95.9 & 3.5 & 1.0 \\
\hline Phosmet & 96.5 & 3.1 & 0.9 & 99.6 & 3.7 & 1.2 \\
\hline Piperonyl butoxide & 94.8 & 4.1 & 1.2 & 90.0 & 5.7 & 1.6 \\
\hline Prodiamine & 98.5 & 4.6 & 1.4 & 96.0 & 5.1 & 1.5 \\
\hline Prometon & 89.9 & 9.5 & 2.7 & 87.8 & 10.2 & 2.8 \\
\hline Prometryn & 85.1 & 5.0 & 1.3 & 84.7 & 7.8 & 2.1 \\
\hline Pronamide (Propyzamide) & 90.7 & 6.0 & 1.7 & 92.0 & 6.1 & 1.8 \\
\hline Propanil & 100.5 & 7.0 & 2.2 & 94.4 & 9.2 & 2.7 \\
\hline Propargite & 94.4 & 7.4 & 2.2 & 91.5 & 8.3 & 2.4 \\
\hline Propyzamide & 87.3 & 5.3 & 1.5 & 88.5 & 6.8 & 1.9 \\
\hline Pyridaben & 91.8 & 4.3 & 1.2 & 94.6 & 4.7 & 1.4 \\
\hline Resemethrin & 95.5 & 4.4 & 1.3 & 96.0 & 5.0 & 1.5 \\
\hline Simazine & 90.2 & 4.7 & 1.3 & 84.2 & 5.7 & 1.5 \\
\hline tau-fluvalinate & 92.9 & 4.0 & 1.2 & 94.5 & 4.3 & 1.3 \\
\hline Tebupirimfos & 95.0 & 5.1 & 1.5 & 88.3 & 7.2 & 2.0 \\
\hline Tefluthrin & 93.4 & 2.3 & 0.7 & 96.2 & 2.7 & 0.8 \\
\hline Tetradifon & 96.9 & 6.4 & 2.0 & 93.5 & 6.0 & 1.8 \\
\hline Tetramethrin & 97.5 & 3.1 & 0.9 & 96.1 & 4.0 & 1.2 \\
\hline Thiazopyr & 96.0 & 6.2 & 1.9 & 97.8 & 6.5 & 2.0 \\
\hline Thiobencarb & 95.7 & 2.0 & 0.6 & 94.6 & 3.6 & 1.1 \\
\hline Triallate & 90.2 & 4.8 & 1.4 & 93.7 & 4.9 & 1.5 \\
\hline Trifluralin & 91.7 & 3.0 & 0.9 & 88.8 & 4.3 & 1.2 \\
\hline
\end{tabular}


Table 4. Summary of method recovery and variability (expressed as mean percent recovery and relative standard deviation) and method detection limits determined from sets of 7 spiked samples of two different sediment matrixes.Continued

[Herbicides/Insecticides indicates carbon/alumina-SPE cleanup. Fungicides indicates Florisil cleanup. Compounds noted with an asterisk are non-fungicides that are amenable to Florisil cleanup. Abbreviations/Acronyms: RSD, relative standard deviation; MDL, method detection limit; $\mu \mathrm{g} / \mathrm{kg}$, microgram per kilogram]

\begin{tabular}{|c|c|c|c|c|c|c|}
\hline \multirow{2}{*}{ Fungicides } & \multicolumn{3}{|c|}{$\begin{array}{c}\text { Northern California } \\
\text { agricultural drain sediment } \\
\text { (1.5 percent organic carbon) }\end{array}$} & \multicolumn{3}{|c|}{$\begin{array}{c}\text { Central California } \\
\text { estuary sediment } \\
\text { (3.7 percent organic carbon) }\end{array}$} \\
\hline & $\begin{array}{l}\text { Percent } \\
\text { recovery }\end{array}$ & $\begin{array}{l}\text { Percent } \\
\text { RSD }\end{array}$ & $\begin{array}{c}\text { MDL } \\
(\mu \mathrm{g} / \mathrm{kg})\end{array}$ & $\begin{array}{l}\text { Percent } \\
\text { recovery }\end{array}$ & $\begin{array}{l}\text { Percent } \\
\text { RSD }\end{array}$ & $\begin{array}{c}\text { MDL } \\
(\mu \mathrm{g} / \mathrm{kg})\end{array}$ \\
\hline Azoxystrobin & 97.9 & 3.0 & 0.9 & 102.0 & 4.1 & 1.3 \\
\hline Boscalid & 96.0 & 3.9 & 1.2 & 100.2 & 5.8 & 1.8 \\
\hline Captan & 83.9 & 11.9 & 3.1 & 84.1 & 12.3 & 3.4 \\
\hline Chlorothalonil & 81.4 & 4.4 & 1.1 & 74.8 & 7.0 & 1.7 \\
\hline Cyproconazole & 98.3 & 3.2 & 1.0 & 93.0 & 3.9 & 1.1 \\
\hline Cyprodinil & 91.8 & 5.8 & 1.7 & 81.2 & 8.6 & 2.2 \\
\hline Difenoconazole & 100.0 & 3.2 & 1.0 & 82.8 & 6.2 & 1.6 \\
\hline Dimethomorph & 87.0 & 5.3 & 1.5 & 93.3 & 6.2 & 1.8 \\
\hline Famoxadone & 92.8 & 5.9 & 1.7 & 81.3 & 8.3 & 2.1 \\
\hline Fenarimol & 101.1 & 4.4 & 1.4 & 83.5 & 7.1 & 1.8 \\
\hline Fenbuconazole & 89.8 & 6.5 & 1.8 & 102.1 & 6.6 & 2.1 \\
\hline Fenhexamide & 92.8 & 8.5 & 2.5 & 94.0 & 11.3 & 3.3 \\
\hline Fluazinam & 94.2 & 6.9 & 2.1 & 96.9 & 8.7 & 2.6 \\
\hline Fludioxinil & 88.8 & 9.1 & 2.5 & 80.3 & 11.1 & 2.8 \\
\hline Fluoxastrobin & 89.9 & 4.4 & 1.2 & 86.9 & 6.2 & 1.7 \\
\hline Flusilazole & 92.1 & 7.4 & 2.2 & 92.5 & 8.6 & 2.5 \\
\hline Flutolanil & 94.9 & 7.1 & 2.1 & 95.9 & 8.1 & 2.4 \\
\hline Flutriafol & 91.9 & 3.6 & 1.1 & 92.7 & 4.6 & 1.4 \\
\hline Imazalil & 91.3 & 6.4 & 1.8 & 89.7 & 7.4 & 2.1 \\
\hline Indoxacarb* & 87.9 & 8.7 & 2.4 & 94.1 & 9.2 & 2.7 \\
\hline Iprodione & 92.6 & 3.0 & 0.9 & 95.1 & 4.4 & 1.3 \\
\hline Kresoxim-methyl & 89.2 & 1.8 & 0.5 & 80.1 & 3.9 & 0.9 \\
\hline Metalaxyl & 86.6 & 6.9 & 1.9 & 87.9 & 8.4 & 2.3 \\
\hline Metconazole & 95.5 & 4.1 & 1.2 & 90.6 & 6.7 & 1.9 \\
\hline Myclobutanil & 96.5 & 5.8 & 1.7 & 91.9 & 7.7 & 2.2 \\
\hline Novaluron & 92.3 & 3.9 & 1.1 & 92.5 & 4.2 & 1.2 \\
\hline Pentachloronitrobenzene & 84.8 & 4.1 & 1.1 & 81.2 & 6.1 & 1.5 \\
\hline Propiconazole & 83.5 & 4.2 & 1.1 & 77.5 & 5.0 & 1.2 \\
\hline Pyraclostrobin & 85.8 & 4.1 & 1.1 & 86.7 & 5.3 & 1.4 \\
\hline Pyrimethanil & 91.0 & 3.7 & 1.1 & 90.1 & 4.9 & 1.4 \\
\hline Tebuconazole & 84.3 & 4.5 & 1.2 & 89.8 & 5.8 & 1.6 \\
\hline Tebupirimfos oxon* & 97.5 & 6.6 & 2.0 & 90.7 & 8.0 & 2.3 \\
\hline Tetraconazole & 92.6 & 3.8 & 1.1 & 82.1 & 6.0 & 1.5 \\
\hline Triadimefon & 86.8 & 5.5 & 1.5 & 91.6 & 6.2 & 1.8 \\
\hline Triadimenol & 92.7 & 5.3 & 1.5 & 83.6 & 6.5 & 1.7 \\
\hline Tribuphos* & 89.1 & 7.9 & 2.2 & 92.7 & 8.5 & 2.5 \\
\hline Trifloxystrobin & 96.9 & 3.4 & 1.0 & 94.8 & 4.1 & 1.2 \\
\hline Triflumizole & 99.0 & 3.4 & 1.1 & 91.9 & 4.5 & 1.3 \\
\hline Triticonazole & 95.9 & 5.9 & 1.8 & 97.8 & 6.5 & 2.0 \\
\hline Vinclozolin & 99.3 & 3.7 & 1.2 & 96.9 & 4.5 & 1.4 \\
\hline Zoxamide & 97.7 & 3.7 & 1.1 & 85.3 & 7.1 & 1.9 \\
\hline
\end{tabular}




\section{Summary}

This method report provides details for the analysis of 119 pesticides in environmental sediment samples. The pesticides are isolated from sediment samples by accelerated solvent extraction with an organic solvent, sulfur is removed via gel-permeation chromatography, and the co-extracted matrix is removed with either carbon/alumina solid-phase extraction or Florisil ${ }^{\circledR}$. Chromatographic separation, detection, and quantification are achieved with gas chromatography and mass spectrometry (GC/MS).

The analytical method showed good precision, with greater than 75 percent recovery and standard deviations of less than 13 percent for all compounds; 96 percent of the compounds in the method had recoveries greater than 80 percent and relative standard deviations less than 10 percent. Method detection limits (MDLs) for individual compounds ranged from 0.6 to $3.4 \mu \mathrm{g} / \mathrm{kg}$ for $\mathrm{GC} / \mathrm{MS}$ for sediment matrices of up to 3.7 percent organic carbon.

\section{References Cited}

Hladik, M.L., Domagalski, J.L., and Kuivila, K.M., 2009a, Concentrations and loads of suspended sediment-associated pesticides in the San Joaquin River, California and tributaries during storm events: Science of the Total Environment, v. 408, no. 2, p. 356-364.

Hladik, M.L., Orlando, J.L., and Kuivila, K.M., 2009b, Collection of pyrethroids in water and sediment matricesDevelopment and validation of a standard operating procedure: U.S. Geological Survey Scientific Investigations Report 2009-5012, 22 p. (Also available at http://pubs.usgs. gov/sir/2009/5012/.)

Hladik, M.L., Smalling, K.L., and Kuivila, K.M., 2009c, Methods of analysis - Determination of pyrethroid insecticides in water and sediment using gas chromatography/mass spectrometry: U.S. Geological Survey Techniques and Methods Report 5-C2, 18 p. (Also available at http://pubs.usgs.gov/tm/tm5c2/)
Norman, J.E., Kuivila, K.M., and Nowell, L.H., 2012, Prioritizing pesticide compounds for analytical methods development: U.S. Geological Survey Scientific Investigations Report 2012-5045, 206 p.

Orlando, J.L., Smalling, K.L., and Kuivila, K.M., 2008, Pesticides in water and suspended sediment of the Alamo and New Rivers, Imperial Valley/Salton Sea Basin, California, 2006-2007: U.S. Geological Survey Data Series 365, $32 \mathrm{p}$.

Radtke, D.B., 2005, Bottom-material samples (ver. 1.1): U.S. Geological Survey Techniques of Water-Resources Investigations, book 9, chapter A8, June 2005, accessed [June 29, 2012], at http://pubs.water.usgs.gov/twri9A/.

Smalling, K.L., and Kuivila, K.M., 2008, Multi-residue method for the analysis of 85 current-use and legacy pesticides in bed and suspended sediments: Journal of Chromatography A, v. 1210, no. 1, p. 8-18.

Smalling, K.L., and Orlando, J.L., 2011, Occurrence of pesticides in surface water and sediments from three central California coastal watersheds, 2008-09: U.S. Geological Survey Data Series 600, 70 p.

Smalling, K.L., Orlando, J.L., Calhoun, D.L., and Battaglin, W.A., 2012, Occurrence of pesticides in amphibian habitats located throughout the United States, 2009-2010: U.S. Geological Survey Data Series Report DS-707, 36 p.

U.S. Environmental Protection Agency, 1997, Guidelines establishing test procedures for the analysis of pollutants (appendix B, part 136, Definition and procedures for the determination of the method detection limit): U.S. Code of Federal Regulations, Title 40, revised as of July 1, 1997, p. 265-267.

Ward, J.R., and Harr, C.A., eds., 1990, Methods for collection and processing of surface-water and bed-material samples for physical and chemical analyses: U.S. Geological Survey Open-File Report 90-140, 71 p. (Also available at http:// pubs.er.usgs.gov/usgspubs/ofr/ofr90140.) 
Publishing support provided by the U.S. Geological Survey Science

Publishing Network, Sacramento and Tacoma Publishing Service Centers

For more information concerning the research in this report, contact the Director, California Water Science Center

U.S. Geological Survey

6000 J Street, Placer Hall

Sacramento, California 95819

http://ca.water.usgs.gov 


\section{हू}

픔

ฏ

ลa 